\title{
Kayak Merkezlerinde Yer Seçimi: Van ve Bitlis İli Örnekleri ${ }^{1-2}$
}

\author{
Location Selection in Ski Resorts: Van and Bitlis Province Examples
}

\author{
Bahtiyar AYDIN* Faruk ALAEDDINNOĞLU**
}

\begin{abstract}
* Arş. Gör., Van Yüzüncü Yıl Üniversitesi, Edebiyat Fakültesi, Coğrafya Bölümü, Van, Türkiye.

** Prof. Dr., Van Yüzüncü Yıl Üniversitesi, Edebiyat Fakültesi, Coğrafya Bölümü, Van, Türkiye.
\end{abstract}

\section{ORCID:}

B.A.: 0000-0003-2333-6001 (D)

F.A.: 0000-0002-1682-7438 (D)

Corresponding Author:

Faruk ALAEDDINOĞLU

Email

falaeddinoglu@hotmail.com

\section{Citation:}

Aydın B. ve Alaaddinoğlu, F., (2020). Kayak Merkezlerinde Yer Seçimi: Van ve Bitlis İli Örnekleri, Journal of Academic Tourism Studies, 1(1): 59-83.

\section{Özet}

Ĕ̆lence turizmi kapsamında değerlendirilen kış sporları Türkiye'nin turizm arzında önemli bir yere sahiptir. Ancak kayak merkezlerinin kuruluş yerleriyle ilgili yaşanan sorunlar kış sporlarında verimsizliğe neden olmaktadır. Bu durum rekreasyon amaçlı turizm faaliyetlerini sinırlandırmakta, kayak merkezlerinin kuruldŭğu illerin gelecekte alacă̆ pozisyon açısından olumsuz durumların ortaya çıkmasına neden olmaktadır. Türkiye'nin birçok ilinde karşılaşılan bu durum Van Abalı Kayak Merkezi ve Bitlis Nemrut Kardelen Kayak Merkezi'nde de mevcuttur. Söz konusu kayak merkezlerinin yer seçiminden kaynaklı verimlilik sorunları bu çalışmaya konu edilmiştir. Dolayısıyla bu çalışmanın amacl, kayak merkezlerinin yanlış yer seçiminden kaynakl sorunların başta ekonomik kayıplar olmak üzere çevresel sorunlar ve olası kış sporları yatırımlarını ne denli olumsuz etkilediği gerçeğini bütün paydaşların bilgisine sunmaktır.

Bu çalışma, Van ve Bitlis illerinin kış turizm potansiyelini konu alan bir Yüksek Lisans tez çalışması kapsamında üretilmiş ve araştırma alanında bulunan kayak merkezlerinin yer seçimlerinin doğruluğu ve verimlilikleri üzerine odaklanmıştır. Kayak merkezlerinin lokasyon özelliklerini saptayabilmek adına konu uzmanlarıyla birlikte üç sezon gözlemler yapılmıştır. Bu bağlamda yer seçiminin doğru ve işletmenin verimli çalışıp çalışmadığını ortaya koymak adına öncelikle konu uzmanları ve işletme yöneticileriyle altışar sorudan oluşan bir mülakat gerçekleştirilmiştir. Ayruca saha çalışması ve mülakatları desteklemek adına Yüksek Lisans tezinde uygulanan ve yirmi üç sorudan oluşan bir anketin üç sorusu bu çalışma için kullanılmıştır. Bütün bu veri toplama araçlarından elde edilen genel sonuç, Abalı ve Nemrut Kardelen Kayak merkezlerinin yer seçimlerinin yanlış olduğunu göstermiştir. Bu nedenle bazı yıllar bütün bir sezon (2018-2019) kayak yapılamamakta, bazı yıllarda ise sadece çok kısıtlı bir süre kayak yapılabilmektedir. Şüphesiz bu durum hem bölgede yaşayan insanlarn rekreatif faaliyet ihtiyacın karşılayamamakta hem de bölgeye yapılabilecek muhtemel kış turizm yatırımlarının önünde büyük bir engel olarak durmaktadir.

Anahtar Kelimeler: Kış turizmi, kayak merkezi, lokasyon seçimi, Van, Bitlis

\footnotetext{
${ }^{1}$ Bu çalş̧ma Van Yüzüncü Y1l Üniversitesi Bilimsel Araştırma Projeleri Koordinasyon Birimi tarafından desteklenen 2015-SOBYL192 nolu Yüksek Lisans tez projesinden üretilmiştir.
}

${ }^{2} \mathrm{Bu}$ çalışma daha önce 1. İstanbul Uluslararası Coğrafya Kongresinde (2019) özet bildiri olarak sunulmuştur. 


\section{Abstract}

Winter sports, which are evaluated within the scope of recreational tourism, have an important place in Turkey's tourism offer. However, the problems related to the establishment locations of ski centers cause inefficiency in winter sports. This case limits recreational tourism activities and causes negative situations to arise in terms of the provinces' future position where ski centers have been established. This situation, encountered in many provinces of Turkey, is also existing for Van Abalı Ski Center and Bitlis Nemrut Kardelen Ski Center. The efficiency problems of these ski centers arising from the choice of location are the subject of this study. Therefore, the purpose of this study is to present to all stakeholders the fact that the problems caused by the incorrect choice of location of the ski centers affect the environmental problems, especially economic losses, and potential winter sports investments.

This study was produced as part of a master's thesis on the winter tourism potential of Van and Bitlis provinces and focused on the accuracy and efficiency of the location selection of the ski centers in the research area. Field observations were carried out for 3 seasons with subject matter experts in order to determine the location characteristics of the ski resorts. In this context, an interview consisting of six questions was conducted primarily with subject matter experts and business managers in order to show whether the location choices are correct and businesses work efficiently. In addition, three questions of a survey consisting of 23 questions applied in the master's thesis were used for this study to support fieldwork and interviews. The overall result from all these data collection tools demonstrated that the location choices of Abali and Nemrut Kardelen Ski resorts were incorrect. For this reason, some years skiing cannot be done for a whole season (2018-2019), while in some years only skiing can be done for a very limited period of time. Undoubtedly, this situation both cannot meet the recreational activity needs of the people living in the region and stands as a major obstacle to possible winter tourism investments in the region.

Keywords: Wintertourism, ski center, location selection, Van, Bitlis

\section{GİRIŞ}

Ekonomik faaliyetler ve yatırımlar için en doğru yer neresidir? sorusu tarihsel olarak oldukça eskiye dayanmaktadır. İlk olarak 1826 da Von Thünen tarımsal konum teorisini (İzole Devlet) geliştirmiştir. Ardından Weber (1909) endüstriyel konum teorisini, Christaller (1933) merkezi yer teorisini ve Losch (1944) ekonomik konum teorisini ortaya koymuştur. İkinci Dünya Savaşı'ndan sonra savaşın yarattığı küresel dönüşümden lokasyon teorisi de nasibini almış ve klasikten modern sahneye geçiş yaşanmıştır. Daha sonrasında Isard (1956), Moses (1958), Smith (1971), Holaham ve Bechman, Lancaster gibi araştırmacılar lokasyon teorisine değişen koşullar, ortaya çıkan yeni dinamikler ve ihtiyaçlar doğrultusunda farklı boyutlar kazandırmışlardır (Fengru \& Guitang, 2019).

Uzun zamandır bilim insanlarını meşgul eden lokasyon (konum) teorisi esasen ekonomik coğrafyanın ve bölgesel ekonominin kalbini oluşturmaktadır (Gorter \& Nijkamp, 2001). Konum teorisi, temelde ekonomik faaliyetlerin nerede yer aldığı ve yer alması gerektiği ile ilgilenmektedir. Teori bir yandan ekonomik faaliyetlerin coğrafi boyutuna açıklama getirirken bir yandan da hem işletmelerin hem de bireylerin davranışlarını analiz etmektedir. Bu açıklama ve analizi yaparken lokasyon teorisi şu sorulara yanıt aramaktadır;

- Bir işletme veya bireyin bir konumu seçmesini sağlayan temel etkenler/güdüler nelerdir?

- Bir işletme veya bireyin faaliyetleri için en uygun konumun özellikleri nelerdir?

- Konum seçim kararının toplumsal, ekonomik, kültürel, siyasal ve mekânsal sonuçları ve uygulamaları nelerdir?

Böylece teori sadece firmaların değil ayn zamanda bireylerin hatta devletin/kamunun yer seçim davranıslan ve bunlarn sonuçlan ile uğraşmaktadır (Yavan, 2020).

Bu bağlamda bu çalışmada bir kayak merkezinin kurulması için "uygun lokasyon neresidir?" ve "sahip olması gereken özellikler nelerdir?" sorularına cevap aranmıştır. Kayak merkezleri için uygun lokasyonun özellikleri ortaya konulduktan sonra Van Abalı Kayak Merkezi ile Bitlis Nemrut Kardelen Kayak Merkezi'nin "yer seçim kararı doğru mudur?" ve "mevcut lokasyon seçiminin sonuçlan nelerdir?" soruları yanıtlanmaya çalışılmıştır. 
Dağlık alanlarda kar varlığına ve tesisleşmeye bağlı olarak gerçekleştirilen kış sporları bugün 67 ülkede yaklaşık 6 milyon yatak kapasitesine sahip (Vanat, 2019) devasa bir turizm faaliyet alanına dönüşmüştür. Turizm gelirlerini artırmak ve bu geliri tüm yıla yaymak için önemli bir araç olan kış sporları turizmine yönelik yatırımlar da dünya genelinde hızlı bir şekilde artmıştır. Pahalı ve lüks bir aktivite olma özelliğine sahip kış sporları (Deng \& vd., 2019) için oluşturulacak tesisler de oldukça yüksek maliyetlerle kurulabilmektedir. Ancak Türkiye'de de birçok örneğini görebileceğimiz üzere gerçekleştirilen yatırımların azımsanmayacak kısmı yanlış yer seçimi nedeniyle istenilen düzeyde, hatta bazen hiçbir katkı sağlayamamaktadır (bkz. Harita 1). Yapılacak yatırımın fiziki ve beşerî gereksinimleri göz önünde bulundurulmadan gerçekleştirilmesi önemli miktarda sermaye ve zaman kaybına yol açabilmektedir. Aynı zamanda bu gibi hatalı uygulamalar bölgeye yapılabilecek başarılı yatırımların da önünü kesebilmektedir. Bu nedenle kayak merkezleri için uygun lokasyon koşullarının belirlenmesi ve yatırımların bu koşulları sağlayan alanlarda gerçekleştirilmesi önem arz etmektedir.

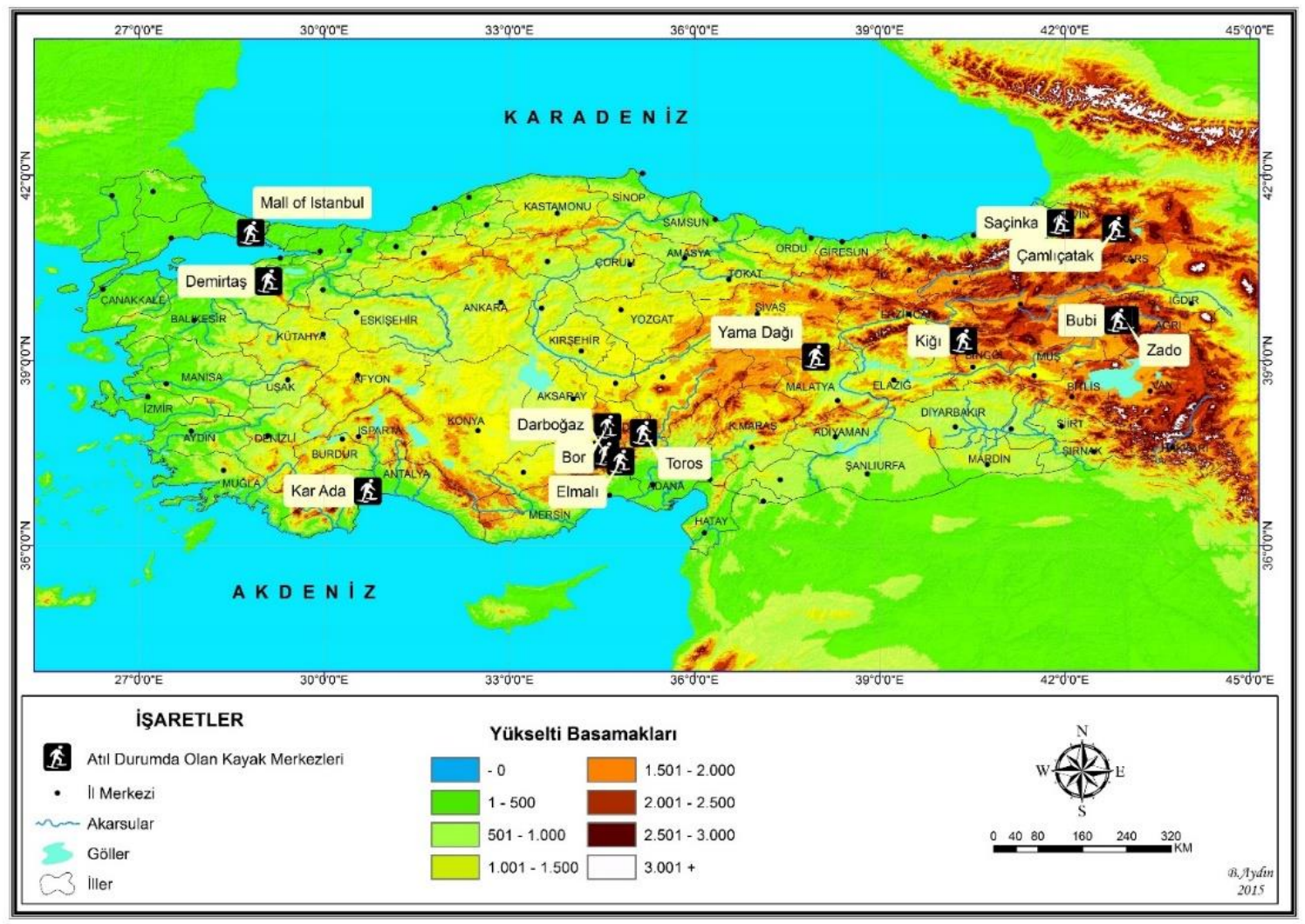

Harita 1: Türkiye'de yanlış yer seçimi nedeniyle atıl durumda kalan kayak merkezleri (Aydın, 2016)

Kış sporlarının gerçekleştirildiği kayak merkezleri, kış sporları yapımına olanak sağlayan dağlık alanlarda konaklama, yeme-içme, eğlence tesisleri ve bunların yan tesisleri ile kayak sporu yapmak için gerekli mekanik altyapı elamanlarının bulunduğu özellikle spor amaçlı düzenlenmiş olan farklı büyüklükteki merkezler olarak tanımlanmaktadır (Ülker, 1992:12). Bu alanlar kayak öğretim alanları, serbest kayma pistleri, yarışma pistleri, kayak mekanik tesisleri ile alt, orta ve üst biniş ve iniş istasyonlarını, çocuk kar bahçeleri, sporcu barınma tesisleri ve kafeteryalar vb. gibi çok sayıda farklı amaçlara hizmet eden donatılar içermektedir (Mızrak, 2011:9). Zira bir kayak merkezinin yukarıda sayılan hizmetlerin tamamını veya bir kısmını verebilmesi büyük ölçüde kuruluş yeriyle doğrudan ilişkilidir.

$\mathrm{Bu}$ bağlamda araştırmaya konu olan her iki kayak merkezinin başta kuruluş yeri olmak üzere, yıl içinde kullanıma açıldıkları süre, tesis altyapısı, verilen hizmetin niteliği ve yeterliliği gibi birçok değişken ele alınmış ve irdelenmiştir. Elde edilen bulgular büyük ölçüde sahayı deneyimleyen uzman kişiler, tesis yöneticileri, sahada yaklaşık üç sezon gözlem yapan araştırmacılar ve günü birlik kullanıcılar üzerinden sağlanmıştır. 


\section{LITTERATÜR TARAMASI}

İlgili alanyazın incelendiğinde kayak alanlarının verimli bir şekilde işletilebilmesinin esas olarak uygun bir doğal çevreye ve yerel sosyo-ekonomik koşullara bağlı olduğu vurgulamaktadır. Kayak alanları, bir yandan arazi ve iklim koşulları gibi doğal koşullar tarafından kontrol edilirken bir yandan da yerel sosyo-ekonomik koşullar tarafından da kontrol edildiğine dikkat çekilmektedir (Gilaberte-Búrdalo \& vd., 2017; Morey, 1984; 1985). Bu nedenle, kayak alanlarının konumlarını belirlemek için hem doğal hem de sosyoekonomik koşullar dikkate alınmalıdır (Fukushıma \& vd., 2002).

$\mathrm{Bu}$ anlamda yapılan çalışmalar irdelendiğinde, araştırmaların mevcut kayak merkezlerinin lokasyon özelliklerine ve potansiyel uygun alanların belirlenmesine odaklandıkları görülmektedir. Örneğin Siberman ve Ress (2010) Kayalık Dağları bölgesinde 2006-2007 sezonunda faaliyet gösteren 85 bağımsız kayak merkezinin konumlarını mevsimsel kar yağış miktarı, potansiyel kayak mevsimi, Ulusal Orman arazisine yakınlık ve kayakçılar ile diğer ziyaretçiler için pazan temsil edecek nüfus merkezlerine yakınlık kriterlerine göre değerlendirmişlerdir. Sonuç olarak da uygun lokasyon seçiminde kullanılabilecek bir CBS modeli ortaya koymuşlardır. Giambrone (2011) ise 6 faktöre göre (ortalama yıllık yağıı̧, ortalama kış sıcaklı̆̆ı, yükselti, otoyola yakınlık, Milli Park Hizmet Alanına göre konum ve büyük nüfus merkezlerine yakınlı) Montana Eyaleti'ndeki kayak merkezi kurmak için uygun potansiyel alanları belirlemeye çalışmıştır. Akın ve Erdoğan (2017) da uzaktan algılama ve CBS sistemlerini kullanarak Aladağlar'da kış sporları için uygun alanları ortaya koymak için kar örtüsü, mevcut arazi kullanım durumu, sayısal yükseklik modelinden elde edilen yükselti, eğim ve bakı verileri kullanılarak tespit etmişlerdir. Ancak bu çalışmada lokasyon seçiminin beşerî koşulları göz ardı edilmiştir.

Literatürde lokasyon seçim kriterlerinin turistlerin destinasyon seçimleri üzerinde etkili olduğunu ortaya koyan çalışmalar da mevcuttur. Pearce (2005) turistlerin destinasyon seçim kararlarını iç ve dış faktörlerin belirlediğini vurgulamıştır. Pearce'ın bu savından hareketle Konu vd. (2011) kış aylarında turistlerin bir kayak merkezine seyahat etme kararının, kişisel özellikler ve güdüler ile kayak merkezinin yokuş kayağı hizmetleri altyapısı, kros kayak hizmetleri altyapısı, restoranlar, sosyal hayat, spa hizmetleri gibi fiziksel özelliklerinin bir sonucu olduğunu varsaymışlardır. Benzer şekilde Klenosky vd. (1993), Riddington vd. ( 2000) ve Von vd. ( 2008 )'nin de elde ettikleri bulgular, kış turistlerinin destinasyon seçiminde kar koşulları ve pist özellikleri başta olmak üzere lokasyondan kaynaklı faktörlerin etkili olduğunu ortaya koymuştur. Dolayısıyla kayak merkezlerinin yer seçim koşulları turistlerin tercihlerini etkilemekte ve destinasyon seçimlerinde belirleyici olmaktadır.

\section{KAYAK MERKEZLERİ İÇİN UYGUN LOKASYONUN ÖZELLİKLERİ}

Kayak merkezlerinin en yüksek verimlilikte kullanılabilmesi kuruldukları alanın doğal ve beşerî koşullarına sıkı sıkıya bağlıdır. Bu nedenle kayak merkezlerinin kuruluşuna etki eden faktörler öncelikle bu iki başlık altında sınıflandırılabilir. 


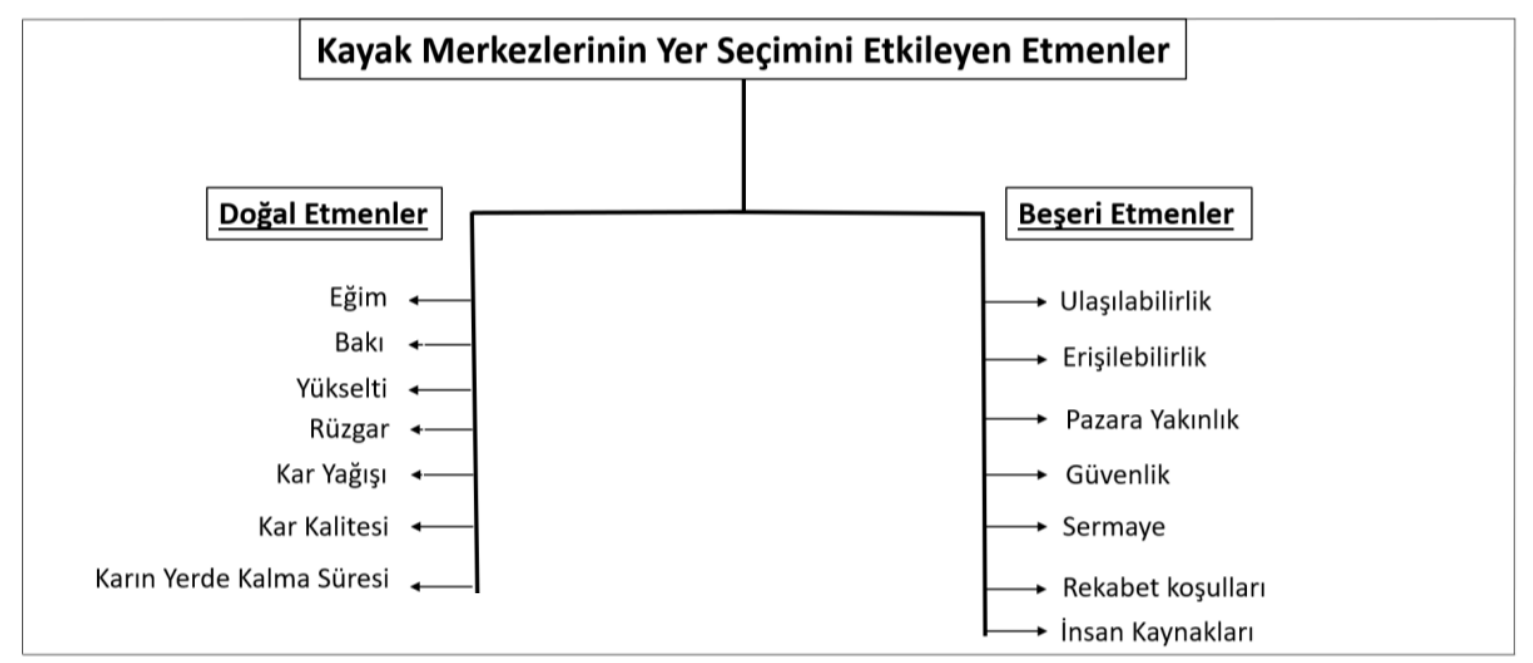

\section{Kayak Merkezlerinin Yer Seçimini Etkileyen Doğal Etmenler}

\section{a) Topografik Etmenler}

Kış sporları kar üzerinde kaymaya dayanan sportif aktiviteler olduğu için yüzey şekillerinin buna imkân verecek özellikte olması gerekir (Aydın, 2016). Kayak merkezlerinin kurulabilmesi için öncelikle kar yağışı alabilecek uygun bir yükseltinin ve çeşitli kış sporlarına olanak sağlayacak farklı eğim şartlarının varlığı en önemli etkenlerdir. Bunların yanı sıra karın yerde kalma süresi ve kar kalitesini doğrudan etkileyen bakı ve rüzgâr koşullarının da uygun olması gerekmektedir.

Yükselti, yeterli ve kaliteli kar yağışı ile karın yerde kalma süresini doğrudan etkilemektedir. Zira yükseltinin artmasına bağlı olarak sıcaklık şartlarında yaşanan düşüşler karın yağması için uygun koşulların oluşmasına olanak tanıdığı gibi (Günal, 2013) karın yerde kalma süresini de doğrudan etkiler. Dolayısıyla kış sporları için en önemli değişkenin yükselti olduğu gerçeği karşımıza çıkmaktadır. Şüphesiz karın yerde kalması ve yağan karın miktarı kıyıdan iç kesimlere doğru gidildikçe de değişmektedir.

Yükselti nedeniyle değişen bir diğer etken ise atmosferdeki nem miktarıdır. Yükselti arttıkça nem oranı düşer (Erol, 2004:204) ve bu durum kar kalitesi açısından önemlidir. Atmosferdeki nem miktarı çeşitli yollarla kar kalitesi üzerinde etkilidir. Bunlardan birincisi yüksek nemliliğin hava durumunda ılımanlaştıııcı etkiye yol açarak karın erimesini hızlandırmasıdır (Demiroğlu, 2013). Erimeye bağlı olarak sulanan kar örtüsü sıcaklığın düşmesiyle donmakta ve kayak için tehlikeli bir zemin oluşturmaktadır. İkincisi ise havadaki nemin yağış esnasında kar tanelerine yapışarak daha sulu bir kar yağışına neden olmasıdır. Bu durum da kış sporları açısından kar kalitesini olumsuz etkilemektedir. Nem seviyesinin düşük olduğu alanlar ise kayak için en uygun olan toz kar oluşumuna olanak vermektedir. Sonuç olarak nemliliğin yüksek veya düşük olması kayak sporunun hem kalitesini hem de güvenliğini etkilemektedir.

Kış sporları açısından irtifa değişikliğinin neden olduğu bir diğer etkende atmosferdeki oksijen miktarında ve atmosfer basıncında meydana gelen azalmadır. Kısa mesafelerde yüksek irtifa farkına maruz kalmak insan sağlı̆̆ı üzerinde olumsuz etkiler yapabilmektedir. Deniz seviyesinden yükseldikçe, oksijen miktarının azalması buna bağlı olarak solunan havanın değişmesi, atmosfer basıncının ve sıcaklığın azalması akciğer ve beyin fonksiyonlarında tahribata neden olabilmektedir (Koyuncu, 2020). Yükseltiye bağlı olarak insan vücudunda meydana gelen fizyolojik değişimlere göre yüksekliğin sınıflandırması şu şekildedir; 1520-2440 m orta irtifa, 2440$4270 \mathrm{~m}$ yüksek irtifa, $4260-5490 \mathrm{~m}$ çok yüksek irtifa, $5490 \mathrm{~m}$ ve üzeri ekstrem irtifa olarak ayrılabilir. $2500 \mathrm{~m}$ ve üzerindeki yükselti değerleri yüksek irtifa hastalıklarının başlayabileceği sınır olarak kabul edilmektedir (İkizceli \& Akdeniz, 2017).

Kayak merkezlerinin kurulabilmesi için uygun olan yükselti kuşağı Uluslararası Kayak Federasyonu (F.I.S.) tarafından belirlenmiştir. Sporcu sağlığını olumsuz etkileyebileceği için 
3000m'nin üzerindeki yükselti kuşağı uygun olmayan alan olarak belirlenmiştir. Ulusal ve uluslararası organizasyonlarda F.I.S.'in kriterleri dikkate alınmaktadır. Örneğin kuzey disiplini yarışları için 1650m'ye kadar olan yükselti kuşağı tercih edilmektedir (Doğaner, 2012). Ancak 3000m yükseltisinin üzerinde karın yerde kalma süresi ve kar kalitesi daha uygun olduğu için bireysel kayak tutkunları için cazip gelebilmektedir.

Sonuç olarak, yükselti faktörü kış sporları için gerekli ve yeterli kar yağışının gerçekleşebilmesi için en önemli etkendir. Uluslararası standartlar ve yerel dinamikler doğrultusunda kurulacak olan bir kayak merkezinin en az 1200-1500m yükselti alt sınırında olması gerekir. Eğer tesis uluslararası ve ulusal müsabakalar için kurulacaksa 3000m üst sinır olarak belirlenmelidir. Bu müsabakalar dışında macera tutkunu turist profiline de hitap etmek isteniyorsa daha üst irtifalara kadar da tesisleşme yapilabilir.

Bakı sözcüğü klimatolojide güneşe dönük olan dağ yamacını ifade etmek için kullanılır. Yarım kürelere göre farklılık gösteren bakı Kuzey Yarım Küre'de güneye, Güney Yarım Küre'de ise kuzeye bakan yamaçtır. Bakı yamacı güneş radyasyonuna daha fazla maruz kaldığından diğer yamaca göre daha fazla ısınır. Bu nedenle karın yerde kalma süresi diğer yamaçla mukayese edildiğinde çok daha kısadır. Aynı şekilde karın erken erimesi, sulanması ve yumuşaması bu yamaçta kar kalitesinin de düşük olmasına yol açar. Bakı yamacının tersi yamaçta ise tam tersi durumlar söz konusudur. Minimum düzeyde güneş radyasyonuna maruz kalan bu alanlarda karın erimesi gecikmekte, yerde kalma süresi uzamakta ve aynı zamanda kar kalitesi daha uzun süre muhafaza edilebilmektedir.

Bakı, kayak merkezleri kurulurken mutlaka göz önünde bulundurulması gereken şartlardandır. Aksi takdirde Nemrut Kardelen Kayak Merkezi'nde olduğu gibi birçok açıdan olumsuz sonuçları ile karşılaşılabilir. Bu gibi durumlara maruz kalmamak için her iki yarım kürede de kendi kutuplarına bakan yamaçlar kayak merkezi kurulumu için tercih edilmelidir. Yani Kuzey Yarım Küre'de kuzey ve ara yönlerine bakan yamaçlar, Güney Yarım Küre' de güney ve ara yönlerine bakan yamaçlar uygundur.

Kış sporları tercih edilen tarza göre farklı eğim koşulları talebi olan bir sportif faaliyettir. Örneğin "kuzey disiplini" tercih edilmişse eğimi az, düz veya düze yakın bir alan tercih konusudur. Çünkü kayaklı koşu(mukavemet-crosscountry) yarışlarıyla karakterize olan kuzey disiplininde yüksek eğim değerleri olumsuzluğa yol açan bir koşuldur. Fakat dünyada çok daha yaygın olan ve yüksek seviyelerden alçak seviyelere kayılarak inilen "Alp Disiplini"nde farklı eğim değerlerine sahip yamaçlara ihtiyaç vardır. Pist olarak kullanilacak olan yamaçların eğimi eğitim, serbest kayak ve yarışmalar için farklılık göstermektedir (Doğaner, 2012).Kış sporları için alanın uygun eğim değerleri \%15 ile \%70 arasında değişmektedir. Ancak ifade edilen rakamlar kış sporlarının niteliğine göre farklılık gösterir. Eğitim amaçlı yapılan sporlar için uygun eğim değeri \%15 iken bu oran serbest kaymada \%50'ye, yarış için olanlarda \%60 ile 70'e yükselir.

Kayak pistleri eğim derecelerine göre sınıflandırılmaktadır. Ülkeden ülkeye birtakım farklılıklar içermekle birlikte pistler zorluk derecelerine göre çeşitli renklerle sembolize edilir. Yeşil, siyah, mavi ve kırmızı renkler en çok kullanılan renklerdir. Aşağıdaki şemada çeşitli ülkelerin pist zorluk derecelerine göre kullandıkları semboller gösterilmektedir.

Tablo 7: Farklı ülkelerde kullanılan pist renk ve sembolleri (Bocchiaro, 2020) (www.travel-information.org, 2020) (https://en.wikipedia.org, 2020)

\begin{tabular}{|c|l|l|l|l|l|}
\hline \multicolumn{2}{|c|}{ Avrupa } & \multicolumn{2}{l|}{ Kuzey Amerika } & \multicolumn{2}{l|}{ Japonya } \\
\hline Renk-sembol & Eğim & Renk-sembol & Eğim & Renk-sembol & Ĕ̆im \\
\hline Eğitim & & En kolay & $\% 6-25$ & Acemi & $\% 6-25$ \\
\hline Kolay & $\% 6-25$ & Orta düzey & $\% 25-40$ & Orta düzey & $\% 40-60$ \\
\hline
\end{tabular}




\begin{tabular}{|c|c|c|c|c|c|}
\hline Orta düzey & $\% 25-40$ & Siyah Elmas & $\% 40+$ & Zor/uzman & $\% 60+$ \\
\hline Zor & $\% 40+$ & ift siyah elmas & $\begin{array}{l}\text { Aşırı dik, } \\
\text { engeller, dar } \\
\text { patikalar, } \\
\text { tehlikeli, en } \\
\text { deneyimli } \\
\text { kayakçılara } \\
\text { uygun }\end{array}$ & & \\
\hline Çok zor & $\% 70+$ & Varyasyonlar & $\begin{array}{l}\text { Artan zorluğu } \\
\text { belirtmek için bir } \\
\text { sembolün iki } \\
\text { katına çıkarılması } \\
\text { veya orta zorluk } \\
\text { derecesini } \\
\text { belirtmek için iki } \\
\text { farklı simgenin } \\
\text { birleştirilmesi } \\
\text { gibi varyasyonlar } \\
\text { kullanılır }\end{array}$ & & \\
\hline & & Parklar & $\begin{array}{l}\text { Yarım borular, } \\
\text { ekstrem spor } \\
\text { engelleri içerir }\end{array}$ & & \\
\hline
\end{tabular}

Uluslararası Kayak Federasyonuda benzer bir pist sınıflaması yapmıştır. Yeşil, mavi, kırmızı ve siyah renklerle sembolleştirilen pistler belli oranda diğer renkteki pistlerin özelliğini taşıyan kısımlara sahip olabilirler. Bu kısımlar genel ortalama eğim değerini etkilemektedir. F.I.S.'ın Alp Kriterlerine göre yaptığı sınıflandırmada kayak pistleri zorluk dereceleri ve özellikleri şu şekilde belirlenmiştir;

Tablo 8: F.I.S. kriterlerine göre pist özellikleri (Gövsa, 2020)

\begin{tabular}{|l|l|}
\hline $\begin{array}{l}\text { Pist } \\
\text { Rengi }\end{array}$ & Özellikleri \\
\hline Yeşil & Acemiler için uygun, \%5-15 arası eğime sahip, pist genişliği en az 30m \\
\hline Mavi & $\begin{array}{l}\text { Orta derece tecrübeliler için uygun, \%25-35 arası eğime sahip, pist genişliği en az } 30 \\
\text { m. }\end{array}$ \\
\hline Kırmız1 & $\begin{array}{l}\text { İyi derecede kayak yapanlar için uygun, \%35-60 arası eğime sahip, genişlik } 30 \mathrm{~m} . \\
\text { Siyah }\end{array}$ \\
\hline
\end{tabular}

Eğim, pistlerin özelliğini belirleyen en temel kriterlerden biridir. Eğim değerine göre hem pistleri kullanacak sporcu kitlesi değişmekte hem de yapılabilecek etkinlikler çeşitlenmektedir. Bu nedenle kayak merkezleri kurulurken tüm zorluk derecelerine sahip yamaçların varlığı büyük önem arz etmektedir. 


\section{b) Klimatolojik Etkenler}

Tesisin konuşlandırılacağı alanın rüzgâr koşulları birçok açıdan yapılacak faaliyetleri etkileyebilmektedir. Doğrudan hava akımlarına açık olan kayak merkezleri birtakım sorunlarla karşılaşmaktadır. Bu sorunlardan ilki pistlerdeki kar örtüsünün süpürülmesidir. Sürekli rüzgâra maruz kalan pistlerde kar örtüsü aşınır ve başka alanlara taşınır. Bu nedenle bazı kısımlarda çıplak zemini yüzeye çıkararak kayak yapılmasına engel teşkil eder. Rüzgârın sıcaklık karakteri de bazen olumsuzluklara yol açabilir. Ilık esen rüzgarlar karın erimesine neden olurken aşırı soğuk estiğinde sporcuları rahatsız edebilmektedir.

Bir diğer önemli sorun ise taşıyıcı sistemlerin güvenliğini tehdit etmesidir. Bir halat vasıtasıyla asılı şekilde hareket eden telesiyej, teleski ve gondol gibi ziyaretçileri taşıyan mekanik sistemler hızlı rüzgarlara maruz kaldığında aşırı sallanmakta ve yolcu güvenliğini tehdit etmektedir. Hatta zaman zaman halatların kopmasına dahi neden olabilmektedir. Rüzgârın neden olduğu bir diğer sorun da sosyal donatıların çatı ve benzer donanımların uçma sına yol açmasıdır. $\mathrm{Bu}$ sebeplerden dolayı kayak merkezi yer seçiminde sahanın rüzgâr koşulları saptanıp mutlaka göz önünde bulundurulmalıdır. Pistlerin kurulacağı alanlarda hâkim rüzgâr yönü, esme sıklığı ve esme hızı gibi meteorolojik gözlemler yapılmalıdır.

Kış sporları kar varlığı ile alakalı bir spor olduğundan kayak merkezlerinin verimliliğini belirleyen en önemli etkenlerden biri de yeterli kar yă̆ışının gerçekleşmesi ve yeterli kalınlığa ulaşabilmesidir. Kış turizminin finansal olarak uygulanabilirliği, yeterli kar koşullarına bağlıdır (Elsasser \& Burki, 2002). Yağış azlığı veya yüksek sıcaklıklar nedeniyle yeterli miktarda kar olmaması, özellikle küresel ısınma bağlamında, kış sporlanı destinasyonları için büyük bir sorundur (Rixen \& vd., 2011). Bu nedenle kayak merkezlerinde kar güvenirliliği büyük önem arz etmektedir. Bir kayak tesisinin kar varlığı açısından güvenilir sayılabilmesi için 1 Aralık' $\tan 15$ Nisan'a kadar en az 100 gün 30cm'nin üzerinde kalınlıkta kar örtüsüne sahip olması gerekir (Rixen \& vd., 2011). Crov vd. yapmış oldukları çalışmada kayak yapabilmek için en az 2,5 cm kar kalınlığının yeterli olacağını savunmuşlardır. Fakat çok az kayak pisti bu kalınlıktaki karda kayak yapmaya imkân verecektir (Scott,. vd. 2007). Çünkü 30 cm 'nin altındaki kar kalınlığı hem kayak ekipmanlarına hem de zemine zarar verilmesine neden olacağından kayak yapmak için uygun değildir (Zeydan \& Sevim, 2008).

Kış sporları açısından karın miktarı kadar kar yağışlı gün sayısı da önemlidir. Ne kadar uzun bir periyotta taze kar yağışı gerçekleşirse pistlerin yüzeyi tazelenecek ve böylece kayak kalitesini artıracaktır. Kar yağış miktarı enlem, karasallık ve yükseltiye göre değişiklik göstermektedir. Karasallık derecesi yüksek, nemli hava kütlelerini karşılayan dağlik alanlar daha fazla kar yağışı alır. Bu alanlarda sıcaklık değerlerinin de düşük olması nedeniyle karın yerde kalma süreside aynı şekilde artış göstermektedir.

Yeterli miktarda kar yağışı gerçekleştikten sonra karın yerde kalma süresi kayak sezonunun uzunluğunu belirlemektedir. Bu nedenle kar örtüsünün yerde kalma süresi kayak merkezinin verimliğini doğrudan etkilemektedir. Karın yerde kalma süresini etkileyen ana etkenler ise yükselti, bakı, nemlilik ve rüzgâr koşullarıdır. Yükselti artıkça sıcaklığın ve nemin azalması karın erimesini yavaşlatır (Demiroğlu, 2014). Kıyılardan iç kesimlere doğru gidildikçe de nemliliğin azalması ve karasallığın artmasına bağlı olarak kar yağışı ve kar örtülü gün sayısı artış gösterir. Bu nedenle yüksek dağlık alanlar daha uzun süre kalın kar örtüsü altında kalır. Fakat günümüzün en önemli küresel sorunlarından olan iklim değişikliği kar yağışları üzerinde de etkilidir. Bu durum kayak merkezlerini de tehdit etmektedir. Öyle ki normal koşullarda herhangi bir problem yaşanmayacak merkezlerde dahi yeterli kar yağışı gerçekleşmeyebilmektedir. Bu nedenle uzun vadeli projeksiyonlar yapılmalı ve iklim değişiklikleri de dikkate alınmalıdır.

Kış sporları için karın kalitesi de çok önemlidir. En kaliteli ve güvenli kayak toz kar üzerinde yapılabilir. Toz kar oluşumu için nemin az, sıcaklıkların da çok düşük olması gerekir (Doğaner, 2012). Bu koşullar altında kristalize olan kar taneleri yumuşak bir zemin oluşturur. Sıcaklık ve nem koşullarının uygun olmadığı alanlarda ise karın kalitesi düşer. 


\section{Kayak Merkezlerinin Yer Seçimini Etkileyen Beşerî Etmenler}

Sadece tek bir değişken üzerinden değerlendirme yaparak lokasyon tercihi yapmak doğru değildir. Kayak merkezleri için kuruluş yeri seçiminde doğal koşulların uygun olması kadar insanla ilişkili çeşitli değişkenlerinde hesaba katılması doğru karar verebilmek için bir gerekliliktir.

$\mathrm{Bu}$ kapsamda kayak merkezinin kuruluş yerinin ulaşılabilir bir lokasyonda olması gereklidir. İnsanların o noktayı kullanabilmeleri için merkezlerin ulaşım sistemlerine entegre olabilecek özelliğe sahip olması gerekir. Pazar olarak hedeflediği alana hizmet verebilmek için gerekli olan ulaşım altyapısının hazır olması yatırımın başarılı olmasını sağlayacaktır.

Bir yatırımin planlanması yeni bir mekânın tasarlanması anlamına gelmektedir. Tasarım yapılırken de herkesin bu alandan faydalanabileceği şekilde planlanma yapılmalıdır. Beklentileri, ihtiyaçları farklı olan kişilerin başkalarına ihtiyaç duymadan buraya ulaşabilmesi gerekir. Bu şekilde farklı sosyal, ekonomik ve kültürel yapıdaki insanların bir mekânı rahatlıkla, kendilerini güvende hissederek kullanabilecek olmaları oranın erişilebilir olduğu anlamına gelmektedir. Bu nedenle kayak merkezlerinin de kuruluş yeri tercihi yapılırken farklı kitlelerin rahatlıkla ulaşabilecekleri ve kullanabilecekleri bir nokta tercih edilmelidir. Ulaşım sistemleri, fiyatlandirmalar ve hizmet yelpazesi bunu desteklemelidir.

Kış sporları tutkuyla yapılan bir spor dalıdır. Bu spora ilgisi olan bir kişi maddi gücünün el verdiği imkanlar doğrultusunda mesafe tanımadan bu deneyimi yaşamak için seyahat edebilmektedir. Ancak kayak merkezlerinin de hitap edecekleri kitlenin kendilerine ulaşabilecekleri mesafede olmaları yani hedeflediği pazara yakın olması oldukça önemlidir. Adeta zamanla bir yarış şeklinde geçen gündelik yaşam içerisinde mesafenin az olması büyük bir çekiciliğe dönüşebilmektedir. Mesafenin çekiciliği ulaşım teknolojileri ile de desteklendiğinde çok daha geniş bir kitleye hitap edebilmenin yolunu açabilmektedir. Özellikle havayolu yatırımları tüm turizm faaliyetlerinde olduğu gibi kış turizmini de önemli ölçüde desteklemektedir.

İnsanlar ancak kendilerini güvende hissettikleri ortamlarda rekreatif faaliyetlerde bulunma eğilimindedirler. Hiç kimse kendisini güvende hissetmediği bir yerde tatilini geçirmek istemez. Kayak merkezleri içinde geçerli olan bu durum, lokasyon tercihinde belirleyici bir etkendir. Güvenlik koşullarının sağlanamayacağı konumlarda bir tesis inşa etmek çok doğru olmayacaktır. Ülkemizde Doğu ve Güneydoğu Anadolu'da yer alan kayak merkezleri bu durumun olumsuz sonuçlarıyla zaman zaman karşılaşmaktadır. Bu bölgelerde güvenlik sorunları nedeniyle zaman zaman faaliyetine ara vermek zorunda kalan tesisler bulunmaktadır (Sarıkamış ve Merga Bütan Kayak Merkezleri gibi). Aynı zamanda afet açısından da güvenli bölgelerin tercih edilmesi elzemdir. Dağlık alanlarda sıklıkla yaşanan çı̆̆, kaya düşmesi gibi afetler bakımından kayak merkezinin kuruluşu için düşük riskli alanlar seçilmeli, ayrıca risk düşük olsa dahi mutlaka gerekli önlemler alınmalıdır.

Yapılan her yatırımın bir maliyeti vardır. Kayak merkezi kurmak da oldukça maliyet gerektiren bir iştir. Bu nedenle masrafları ve hizmetleri karşılayacak bir sermayenin varlığı yatırımı gerçekleştirebilmek için ön koşuldur. Tesisin kurulacak olduğu yer seçilirken de sermaye miktarı belirleyici olacaktır. Sermayenin büyüklüğüne göre tesis kapasitesi belirlenebilecek ve bu kapasiteye göre de yer tercihi yapılacaktır.

Tesisin kurulacağı bölgenin yakınlarında bulunan diğer tesislerde rekabet koşulları açısından kuruluş yeri karar aşamasında göz önünde bulundurulmalıdır. "Kurulacak yeni tesisin diğer ya da diğerlerinden artı yönü ne olacaktır?" ve "İnsanlar neden onları değil de yeni yatırımı tercih etsinler?" sorularının yanıtı hazır olmalıdır. Bunun için doğru bir pazarlama ve tanıtım stratejisi geliştirilmelidir. Kurulacak yeni tesis için yakındaki, çevredeki diğer kayak merkezlerinin gölgesinde kalmayacak ve rekabet edebilecek bir lokasyon seçilmelidir.

Bir yatırımın sürekliliği ihtiyaç duyulan insan kaynaklarının varlığı ile mümkündür. Planlamadan uygulamaya ve işletmeye kadar tüm süreçlerde kalifiye iş gücüne ihtiyaç vardır. Kayak merkezinin kaliteli ve sürdürülebilir hizmet üretebilmesi buna bağlıdır. Bir kayak 
merkezinin kayak eğitmeni, mekanik tesis ve araç-gereç operatörü, yeme-içme çalışanları gibi çeşitli alanlarda yetişmiş elemanlara ihtiyacı vardır. Bu nedenle gereksinim duyulan işgücünü eğitecek alt yapının da önceden hazırlanmış olması gerekmektedir.

\section{YÖNTEM}

Van ve Bitlis illerinin kış turizm potansiyelini konu alan bir Yüksek Lisans tez çalışmasının bir bölümünü oluşturan bu çalışma, kış spor faaliyetlerinin gerçekleştirildiği kayak merkezleri için yanlış lokasyon tercihlerinin hangi sonuçları doğurduğu üzerine odaklanmaktadır. Bu bağlamda belirlenen kriterler kapsamında Van İli'inde bulunan Abalı Kayak Merkezi ve Bitlis İli'nde bulunan Nemrut Kardelen Kayak Merkezi'nin kuruluş yerlerinin uygunluğu araştırmaya konu edilmiştir. Zira bu çalışmayla kayak merkezlerinin kuruluş yeri seçimine dikkat edilmesi gerektiği, aksi taktirde ekonomik kayıpların yaşanacağı, insanların rekreatif amaçlı kayabilme şanslarının ellerinden alınabileceği ve daha önemlisi bir kış spor merkezi olabilme şansının nasıl yok edilebileceği gösterilmeye çalışılmıştır.

Çalışmanın amacına hizmet etmek adına alan çalışmaları ve mülakatlar gerçekleştirilmiştir. Öncelikle, yer seçiminde en doğru kararı verebilmek adına Yüksek Lisans çalışması süresince yaklaşık üç kayak sezonu boyunca kayak eğitmenleriyle birlikte hem Bitlis hem de Van'da araştırmaya konu olan sahalarda gezi ve gözleme dayalı birçok saha çalışması gerçekleştirilmiş ve konuya ilişkin veriler toplanmıştır. Bu bağlamda Van ve Bitlis illerinde kayak merkezi yer seçiminde, öncelikle en doğru değerlendirmeyi yapacağını düşündüğümüz aktif kayak eğitmenleriyle görüşmeler gerçekleştirilmiştir. Görüşülen kişiler hem kayak sporu açısından uzman ve eğitici kimliğe sahip olmaları hem de uzun yıllardır bölgede yaşayan insanlar olmaları nedeniyle tercih edilmişlerdir. Söz konusu kişilerle özellikle kayak sezonu olarak adlandırılan zaman aralığında (Aralık-Şubat arası) alan gezileri yapılmış ve bu geziler süresince hem mevcut kayak merkezlerinin durumuna yönelik sorular yöneltilmiş hem de alternatif alanların varlığı değerlendirilmiştir. Nemrut kardelen kayak merkezinde üç kayak hocası ve Abalı kayak merkezinde ise iki kayak hocası ile altı sorudan oluşan bir mülakat yapılmıştır. Görüşmeler farklı zaman aralıklarında gerçekleştirilen saha araştırmaları sırasında tüm günü kapsayacak şekilde yapılmıştır. İkinci olarak kayak merkezlerinde yer alan işletmelerin yöneticileriyle (2 kişi) yer seçimi ve verimlilik üzerine altı sorudan oluşan bir mülakat gerçekleştirilmiştir.

Üçüncü olarak da nicel araştırma yönteminin veri toplama aracı olan anket tekniği kullanılmıştır. Alaeddinoğlu vd.' (2011)nin “Van Gölü Havzası Batı Kesiminde Ekoturizm Potansiyel Kaynaklarının Derecelendirilmesi ve Turist Profilinin Belirlenmesi" amacıyla yapmış oldukları çalışmada kullandıkları anket formu kış turizmine uyarlanmış ve bu çalışmada kullanılmıştır. Anket çoktan seçmeli ve 5'li Likert ölçekli sorulardan oluşmaktadır. Ancak bir Yüksek Lisans tez çalışmasında kullanilan bu anketin kapsamı oldukça geniş tutulmuştur. O nedenle söz konusu anketin sadece kayak merkezlerinde yer seçimine yönelik olarak hazırlanan üç sorusu bu araştırmaya eklenmiştir. Bu üç soru aracılığıyla bölgeyi deneyimleyen kişilerin gözünden kayak merkezlerinin yeterliliği ve memnuniyet derecelerinin ne olduğu öğrenilmeye çalışılmıştır. Bu kapsamda Abalı' da 186 ve Bitlis'te 168 olmak üzere toplamda 354 kişiye anket uygulanmıştır.

Araştırmaya konu olan alanlar büyük ölçüde yerel katılımcılara hizmet veren küçük ölçekli kayak merkezleridir. Dolayısıyla evreni her ne kadar Van ve Bitlis illeri olsa da, örneklem seçimi Abalı ve Nemrut kayak merkezlerini kullanan ziyaretçiler olmuştur. Bu örneklem grubu basit rastgele örneklem seçme yöntemiyle oluşturulmuştur. Her iki kayak merkezinde de kayak yapan kişi sayısının en yoğun olduğu günlerde dahi birkaç yüz kişiyi geçmediği ifade edilmiş ve bu kapsamda örneklemin sayısal doğruluk verebilmesi için $\% 05$ hata payıyla 350 kişinin yeterli olacağı anlaşılmıştır. Ulaştığımız anket sayısı itibari ile 4500 kişilik bir evrenin temsil edildiği (Gürbüz \& Şahin, 2017) düşünüldüğünde çıkan sonuçların alana ilişkin sağlıklı sonuçlar vereceği söylenebilir. Bu kapsamda yapılan anketler güvenirlik analizine tabi tutulmuş ve her iki kayak merkezinde yapılan anketlerin güvenilir oldukları anlaşılmıştır. Abalı Kayak merkezinde uygulanan anketlerin Crosbach Alpha değeri 0,813; Nemrut Kardelen Kayak Merkezinde ise 0,869 
olarak tespit edilmiştir. Söz konusu anket sorularına verilen cevaplar sadece frekans analizine tabi tutulmuştur.

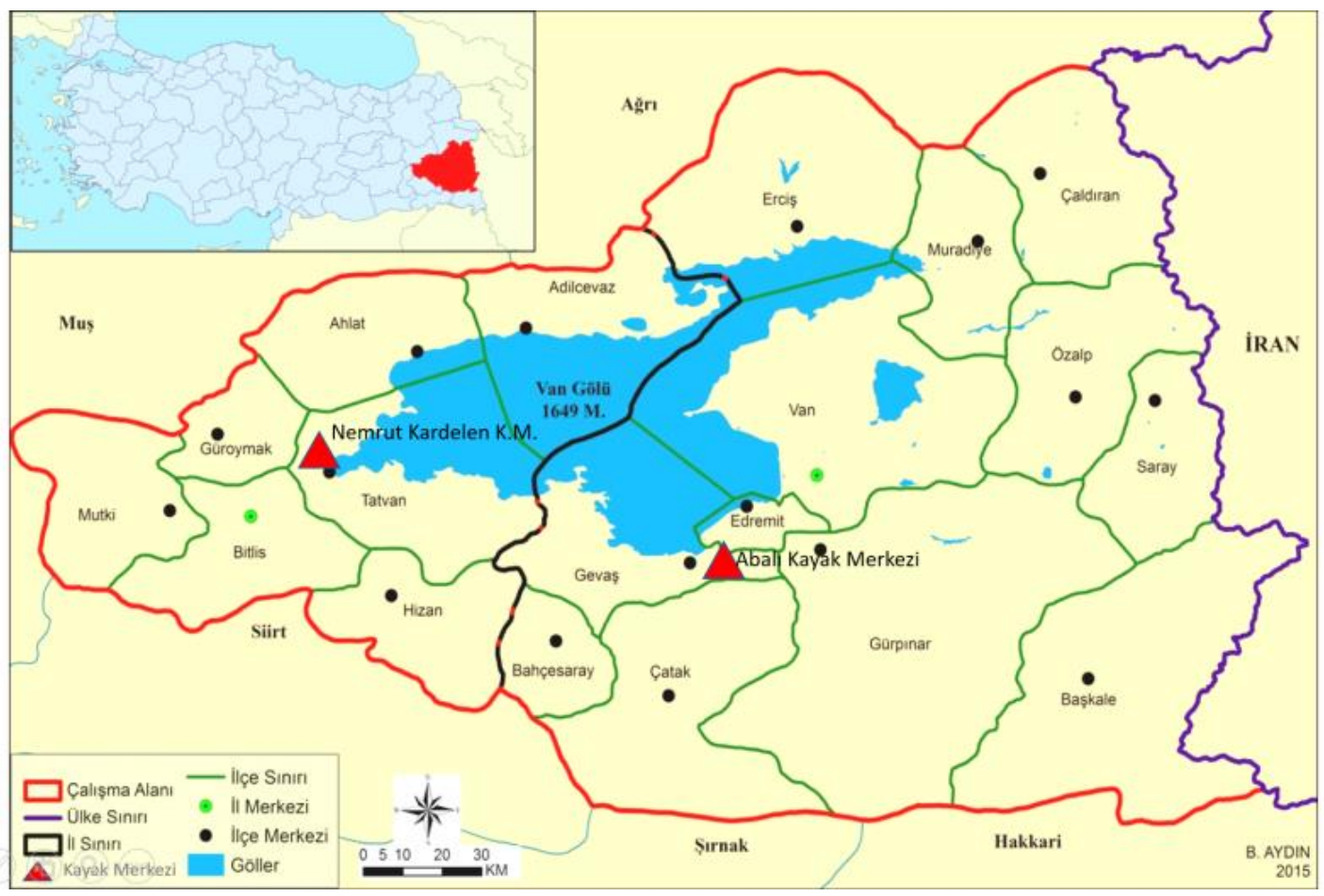

Harita 2: Örneklem kayak merkezlerinin lokasyonu.

\section{BULGULAR}

\section{Nemrut Kardelen Kayak Merkezi Kuruluş Yeri Değerlendirmesi}

Nemrut Kardelen Kayak Merkezi, Bitlis İli Tatvan ilçe merkezine yaklaşık 8 km mesafede bulunmaktadır. Tesis, 2948 m yükseltiye sahip Nemrut Dağı'nın Van Gölü'ne bakan güney yamacında $2246 \mathrm{~m}$ ile $2770 \mathrm{~m}$ kotları arasında 2007'de hizmete açılmıştır. Merkezde 2550 metre uzunluğunda 288 sandalyeli ve $1000 \mathrm{kişi} /$ saat taşıma kapasitesine sahip bir telesiyejle zirveye ulaşılabilmektedir. Farklı zorluk derecelerine sahip 4 adet pisti vardır. Ayrıca tesiste 32 oda ve 40 yatak kapasitesine sahip bir de otel yer almaktadır.

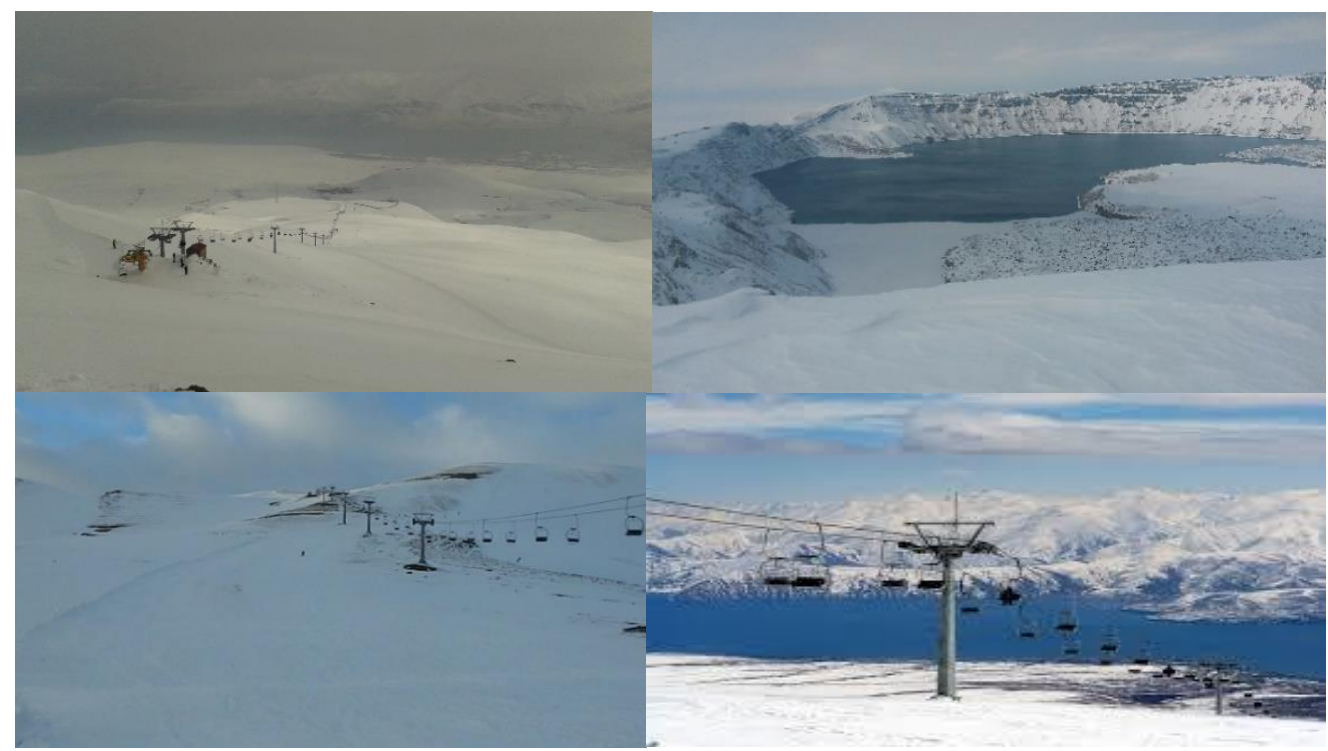

Fotoğraf 1: Nemrut Kardelen Kayak Merkezi'nden genel görünüm. 
Genel olarak kayak merkezi, yeterli miktarda kar yağışı almasına imkân veren uygun bir yükselti kuşağında ve farklı zorluk derecelerinde pist oluşturmaya elverişli bir yamaçta konumlanmıştır. Ayrıca dünyanın en büyük ikinci kaldera gölü ve Van Gölü manzarası sayesinde peyzaj değeri açısından da oldukça iyi bir konumdadır. Muş Havalimanı'na 60 km, Van Ferit Melen Hava Limanı' na $135 \mathrm{~km}$ ve Bitlis İl Merkez'ine $22 \mathrm{~km}$ mesafede bulunmaktadır. Tesise Tatvan ilçe merkezinden asfaltlanmış iyi durumda olan bir yol ile ulaşımın sağlanıyor olması önemli bir avantajdır. Ancak sadece özel araçla ulaşılabilmesi erişilebilirliği bir miktar azaltsa da Van, Muş ve Bitlis yerleşmelerine yakın olması yerel pazar açısından olumlu bir görüntü çizmesine neden olmaktadır. Ayrıca yakınında bulunan diğer üç kayak merkezine göre tesis altyapısı, pist uzunluğu, pist genişliği ve manzarası nedeniyle rekabet açısından da avantajlı gözükmektedir.

Tüm bu olumlu özelliklerine rağmen tesis, doğal koşulların sağlanmadığı bir lokasyonda yer almaktadır. Öyle ki bakı ve rüzgâr koşulları kayak merkezinin bahsettiğimiz bütün olumlu yönlerini gölgeleyecek sonuçlar doğurmaktadır. Nitekim güney yamaçta kurulması nedeniyle tesisin bulunduğu alan gün boyu yüksek güneş radyasyonuna maruz kalmaktadır. Bu durum hem kar kalitesini hem de karın yerde kalma süresini olumsuz etkilediğinden tesisin verimli bir şekilde çalışmasını engellemektedir.

Yapılan gözlemler ve görüşmeler sonucunda tespit edilen en temel olumsuzluğun rüzgâr koşullarına bağlı olarak ortaya çıktığı anlaşılmıştır. Zira topografik açıdan Rahva Düzlüğü olarak bilinen ve Muş Havzası'yla Van Gölü Havzası'nı ayıran boğazın bir rüzgâr koridoru özelliği olması ve Nemrut Kayak Merkezi'nin bulunduğu noktanın tam bu boğazın karşısına denk gelmesi tesisin sürekli ve şiddetli rüzgâr almasına neden olmaktadır. Sürekli rüzgâra maruz kalmasından dolayı pistlerin bazı noktaları süpürülerek kar örtüsü incelmekte veya tamamen kaldırılmaktadır. Buna bağlı olarak da sporcuların düzenlenmiş pistler yerine karın yığıldığı düzensiz alanlar üzerinde kaymak zorunda kaldıkları gözlemlenmiştir.

Tamda bu anlamda bu görüşleri doğrulamak adına kayak merkezini kullanan ve bölgede aktif eğitmenlik yapan üç kayak öğretmeniyle görüşmeler gerçekleştirilmiştir. Kayak eğitmenlerine konuyla ilgili altı soru yöneltilmiş ve aşağıda yer alan cevaplara ulaşılmıştır.

Birinci soru "Kayak merkezi doğru yerde kurulmuş mu?" şeklindedir. Bu soruya Nemrut kardelen kayak merkezindeki N. E1 ve N. E3 şu şekilde cevap vermişlerdir. Kayak merkezinin kurulduğu yer sıkıntıl maalesef. Böylesine güzel bir işletme ne yazık ki yanlış yerde kurulduğu için çoğunlukla çalışamıyor. Bu bölgenin en fazla rüzgâr alan kısmı burası. Bu nedenle kaç kez çatılar uçtu, halatlar koptu. Büyük tehlike yaratıyor. Çoğunlukla bu nedenle hizmet veremiyoruz. Aynı zamanda rüzgâr pistlerde kar bırakmıyor. Süpürüp götürüyor. Bir de burası güneye bakıyor. Bu nedenle güneş karın yerde kalma süresini ve kalitesini olumsuz etkiliyor. Kuzey yamaçlarda Nisan sonuna kadar kar dururken bizim pistlerde çok daha erken kalkıyor. Kaymak için yeterli kar olsa bile bu sefer çok güneş aldığı için öğleden sonra kar yumuşuyor ve kayak kalitesini düşürüyor. Sabah saatlerinde ise sulanan kar geceden dona çektiği için tehlike yaratıyor. Bu sebeplerden dolayı yer seçiminin doğru olmadığın dü̧̈ünüyorum. N.E3 ise yukarıdaki görüşlerin benzerlerini ifade etmiş ancak bir farklı yaklaşım getirmiştir. $O$ da özellikle kayak tesisinin yapıldığı yıl kar yağışının fazlaca yağdığını ve tesisin kuruluş yerini belirleyen kişilerin muhtemelen bu duruma göre karar verdiklerini söylemiştir.

N.E3'ün cevabindan sonra ikinci soru daha da anlam kazanmaktadır. Zira bir yıllık kar yağışı yer tespitinde önemli olabilir mi? Sorusunun cevabı kesinlikle hayır olmalı. İkinci soru, "Kayak merkezi kuruluşunda sizlerin görüşü alındı mı?" Bu soruya iki eğitmen hayır cevabını vermiştir. Eğitmenler, kimse bize bir şey sormadı. O dönemin idarecilerinden biri buraya kurun demiş kurulmuş. Göle bakarak kayak yapsin vatandaşlar demiş. Hiçbir fizibilite yapılmamdan, uzman kişilerin görüşü alınmadan. Sonuç ortada... ancak N.E3 kayak merkezi inşaatı devam ederken yerel 
yöneticinin kendisini çağırdığını ve tesisin yeri hakkında görüşünü aldığını ifade etmiştir. Ancak tesisin inşaatı durmaksızın devam etmiştir.

Eğitmenlere yöneltilen üçüncü soru ise "Kayak merkezinin kar kalitesi ve karnn yerde kalma süresi hakkında ne düşünüyorsunuz?" Şeklinde olmuştur. N.E1 Normal şartlarda bu bölgenin kar kalitesi ve sezon uzunluğu kayak sporu için çok uygun. Ancak az öncede söyledim. Tesis yanlış yamaçta kurulmuş. Hem rüzgâr hem güneş kar kalitesini olumsuz etkiliyor. Sezonun da kısalmasına sebep oluyor. Rüzgâr zaten yeterli kar olsa dahi çoğunlukla hizmete ara vermememize neden oluyor. Bazen koca sezon içinde toplam 10-15 gün kadar hizmet verdiğimiz oluyor. N.E2 Kar kalitesi aslında iyi ancak karın yerde kalma süresiyle ilgili sorunu var. Yă̆an kar ya eriyor ya da rüzgâr tarafindan süpürülüyor. Bu da kayak yapmanızı engelliyor. Zaman zaman ot kökleri ve kayaçlar yüzeye çıkıyor ve sakatlı yaratan yaralanmalara da neden olabiliyor. N. E3 Bu bölgede yağan karn miktarı özelikle son yıllarda hem azaldı hem de daha sulu gibi... eskiden daha çok kar yağardı. Ama her geçen yıl kaymak daha zor sanki.

Araştırmada eğitmenlere yöneltilen dördüncü soru "Kayak sezonunun uzunluğunda süreç içerisinde bir değişiklik oldu mu?" Bu soruya özellikle N. E3'ün cevabı oldukça anlamlıdır. Bu kayak merkezi ve çevresinde henüz kayak merkezi yapılmadan önce de biz bu bölgede zirve tırmanışlar yapar ve inerken de kayakla inerdik. O yillarda çok kar yağardı ve yerde zaman zaman bir metreden çok fazla kar olurdu. Dă̆ın tamamı beyaza bürünürdü. Birde kar yağışları ta ekimde başlardı. Ancak bugün aralıkta bile zor kar yă̆ar oldu. Yă̆an karda hem az hem de kalitesiz. N. E1. Normalde Aralık-Nisan arasında beş aylık bir sezonumuz var. Fakat bahsettiğimiz sorunlar nedeniyle biz bu sezondan faydalanamıoruz. N. E2. ise kayak sezonunun her geçen yıl azaldığını ve bazı yıllar hiç kayılamadı̆̆ıı ifade etmiştir.

Eğitmenlere yöneltilen beşinci soru "Sizce bu merkez ulusal ve uluslararası organizasyonlara hizmet verebilir mi?" N. E1 ve N. E2. Maalesef yapamaz. Bu tarz organizasyonlar çok önceden planlantr. Organizasyonun yapılması düşünülen kayak merkezinin bu plana dahil edilebilmesi için insanlarn kafasında soru işareti olmaması lazım. Acaba o dönemde aktif çalışma koşullarına sahip olabilir mi diye? Bizim daha önce yerel ölçekte bu tarz girişimlerimiz oldu fakat olumsuz hava koşullarn nedeniyle yarışlan Çiftkaya'da yapmak zorunda kaldik. Yerel bir organizasyonu bile gerçekleştirilemezken ulusal ya da uluslararası bir organizasyon gerçekleştirmek bence mümkün değil. N. E3. ise bölgenin yeterince su kaynağına sahip olduğunu ve yapay kar ile bu sürecin gerçekleştirilebileceğini ifade etmektedir. Altınc1 soru ise "Kayak merkezi bölge insanının ihtiyacını karşılıyor mu?" şeklinde olmuştur. Bu soruya her üç

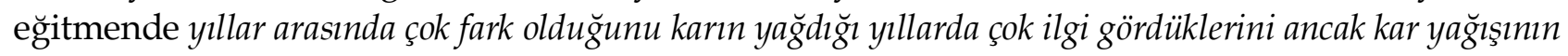
yeterince gerçekleşmediği yıllarda maalesef ihtiyacı karşılayamadığ yönünde olmuştur. Ayrıca tam kapasiteli çalışamadiğg için tesislerde çoğunlukla atıl kalmakta ve en temel ihtiyaçlar dahi karşılanamamaktadır. Görüleceği üzere üç eğitmen de tesisin yeri konusunda yanlışlık yapıldığı ve karar verme süreçlerinin de sağlıklı işlemediğini göstermişlerdir.

Yer seçimim konusunda eğitmenlerin yanı sıra kayak merkezlerinde hizmet veren işletme yöneticilerinin de görüşü alınmıştır. Bu anlamda işletme yöneticisine altı soru yöneltilmiştir. Birinci soru "İşletmeniz kaç ay açık kalıyor?" şeklindedir. Bu soruya işletme sahibinin verdiği cevap şu şekildedir. Standart bir zaman aralığı belirtmek zor. Bazen tüm sezonda toplam bir-iki hafta kadar anca açık kaldığımız dönemler olabiliyor. Tüm sezonu etkin kullanabildiğimiz bir zamanımız olmadı hiç. İkinci soru "Ziyaretçileriniz ağırlıkl olarak nereden geliyor?" Daha çok bölge insanlan gelir. Tatvan, Bitlis ă̆ırlıktadır. Bunların dışında Van ve Muş'tan gelenler olur hafta sonları. Bazen Türkiye'nin farklı bölgelerinden gelenler de olur özellikle Kalderayı görmek, fotoğraflamak için.

Üçüncü Soru "Burayı ziyaret edenler kayak deneyiminden memnunlar mı?" "Açıkçası buraya gelen ziyaretçilerin çok kü̧̈ük bir azınlığı profesyonel kayakçıdır. Çoğunluğu kayakla yeni tanışmış ve daha çok acemi kişilerden oluşmaktadır, dolayısıyla yüksek beklentileri yok. Hizmet verebildiğimiz sürece onları memnun edebiliyoruz. Fakat profesyonellerin beklentisini karşılayacak pist koşullarımız günün kısıtlı bir saatine sıkışıyor. Sabahın erken saatleri ve öğleden sonralar kar kalitesi düştüğü için pek memnun 
olmuyorlar". Dördüncü Soru daha çok kayak merkezinin yerini sorgulama ya yöneliktir. Zira çalışmanın temel amacı bu kapsamda ele alınmıştır. Dolayısıyla işletme sahiplerinin de bu konudaki kanaatleri çalışmanın geçerliliği adına önemlidir. "Sizce bu yer kayak merkezi için uygun mu? "Yani pek değil. Biz işletmeciyiz. Büyük umutlarla işletme hakkını aldık buranın. Fakat umduğumuz gibi olmadı. Çünkü tam kapasite çalışamıyoruz. Rüzgârdan dolayı telesiyej halatları kopuyor, çatılarımız uçuyor. Bunların hepsi büyük masraflar çıkarıyor. Bu süreçte hizmet de veremiyoruz. Mesela otelimiz var burada ama hiç işletmeye açmıyoruz bile. Isıtamıyoruz. Elektrik kesintisi çok sık oluyor. Pistlerde kar tutamıyoruz. Ayrıca bütün bunlar işletmenin giderlerini dahi karşılayamaması durumunu ortaya çıkardığ̆ gibi hizmet kalitesinden ödün verilmesine ve müşteri memnuniyetsizliğine yol açabiliyor.

Beşinci soru sorunların çözüm yolunun ne olduğunu anlamaya yöneliktir. "Altyapı ve üstyapı imkânlar iyileştirilirse ziyaretçi sayısı artar mı?" sorusuna; "Zannetmiyorum. Bir kayak merkezi kayakçıların beklediği kayma koşullarını sağlayamıyorsa bu anlamda başarılı olması pek mümkün değil. Ancak tesis doğal koşulların daha uygun olduğu bir alana taşınırsa belki mümkün olabilir." şeklinde verilen yanıt çözümün lokasyon değişikliği ile olabileceği görüşümüzü desteklemiştir. Altıncı soru da ise yiyecek-içecek işletmesinin verimliliği ölçülmeye çalışılmıştır. Bu kapsamda işletme sahibine "Kayak merkezine gelen kişiler bu işletmeleri (yiyecek-içecek amaçli) ne sıklıkta (ölçüde) kullanıyor." Burada bu konuda hizmet veren bizden başka işletme yok. Bu nedenle burayı ziyaret eden misafirlerimizin hemen hemen hepsi bizden alışveriş yapıyor. Fakat tabi buraya mangalıyla, semaveriyle vs. gelip piknik yapanlarla da oluyor. Sonuç olarak işletme sahibi tarafından verilen tüm yanıtlar da Nemrut kayak merkezinin kuruluş yerinin yanlış olduğunu doğrulanmıştır.

Eğitmenler ve işletme sahibiyle yapılan mülakatlara ek olarak çalışmanın sağlıklı sonuçlar doğurması için alanı kullanan 167 ziyaretçiye anket uygulanmıştır. Ankete katılanların çoğunluğu tesisin kar kalitesini yeterli bulmuşlardır (bkz. Tablo:3). Ancak unutulmaması gereken, tesiste kayak yapan ve ankete katılan süjelerin büyük çoğunluğunun yöre insanı oldukları ve kendilerini de kayak sporcusu olarak görmedikleri gerçeğidir. Dolayısıyla, kayak sporunu amatörce yapmaları ve kaliteli bir kayağın nasıl bir zemin üzerinde yapılabileceği hakkında yeterli bilgi ve deneyime sahip olmamaları böylesi bir sonucun çıkmasında belirleyici olmuştur.

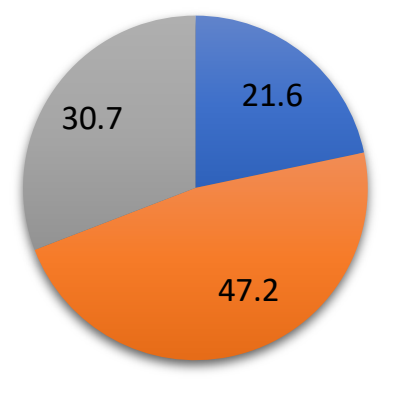

Tesadüfi Kış Turisti

Normal Kış Turisti

Kış Sporlarına Etkin Katılan Turist

Grafik 1: Nemrut Kardelen Kayak Merkezini deneyimleyen ziyaretçilerin profili

Tesisin en önemli çekiciliğinin ne olduğu sorusuna verdikleri yanıt da bu görüşümüzü desteklemektedir. Nemrut kayak Merkezinin yaşadıkları yere yakınlığı ile manzara ve doğal güzelliklerini kendileri için en önemli çekicilik olarak ifade eden katılımcıların sadece \%7,8'i kar kalitesini en önemli çekicilik olarak görmüştür. Buda ziyaretçilerin çoğunluğu için kar kalitesinin bir çekicilik kaynağı olmadığını göstermektedir. Oysa kar kalitesi kayak tutkunları ve profesyonel kayakçılar için her türlü kış sporu aktivitelerinin temelini oluşturmaktadır (Hodeck \& Hovemann, 2015). 
Tablo 9: Nemrut Kardelen Kayak Merkezi'nin katılımcılara göre en önemli çekiciliği

\begin{tabular}{|l|l|l|}
\hline \multicolumn{2}{|l|}{ Sizce bu merkezin en önemli çekiciliği nedir? (\%) } \\
\hline & Kişi sayısı & $\%$ \\
\hline Yaşadığım yere yakınlık & 70 & 42,2 \\
\hline Manzara ve doğal güzellikler & 65 & 39,2 \\
\hline Tesis ve pist kalitesi & 15 & 9,0 \\
\hline Kar kalitesi & 13 & 7,8 \\
\hline Hizmet kalitesi & 1 &, 6 \\
\hline Diğer & 2 & 1,2 \\
\hline Toplam & 167 & 100,0 \\
\hline
\end{tabular}

Kayak merkezleri müşterilerini memnun edebilmek için birçok hizmeti bir arada vermek durumundadırlar. Kaliteli konaklama, yeme-içme hizmetleri, eğlence imkanları, farklı rekreasyon olanakları bunlardan bazılarıdır. Hizmetlerin çeşitlenmesi ve istenilen kalite düzeyine ulaşabilmesi için istikrarlı bir talebin varlığı büyük önem arz eder. Talebin istikrarlı olabilmesi için ise şüphesiz kayak merkezinin her yıl aksamadan hizmet verebilmesi gerekmektedir. Kesintisiz ve kaliteli hizmet üreten bir tesis her geçen yıl daha fazla tercih edilir ve buna bağlı olarak da yatırımlar artar. Sonuç olarak gerçekleştirilecek yatırımlar alt yapının güçlenmesine ve doğal olarak müşteri memnuniyetine dönüşecektir.

Ancak Nemrut'taki tesisin konumlandığı lokasyonun uygun olmaması kesintisiz hizmet üretmesinin önündeki en büyük engeldir. Kuruluş yeri seçiminden kaynaklanan hatalar bazen tesisin sezonun büyük kısmında, bazen de bütün bir yıl atıl kalmasına neden olmaktadır. Bu durum kayak merkezini tatil planına dahil edecek insanlarda olumsuz bir kanaate ve tercihlerini başka yerlerden yana kullanmaya itmektedir. Şüphesiz bu durum talebin azalmasına neden olduğu gibi hizmet kalitesinin de düşmesine yol açmaktadır. Kaldı ki işletme sahibi Nemrut'ta söz konusu bakı ve rüzgâr koşullarının yarattığı olumsuzluklardan kaynaklı tesisin sık sık hizmetine ara verdiğini ve doğal olarak işletmenin de oldukça verimsiz bir şekilde çalıştığını ifade etmiştir. Zira katılımcıların kayak merkezi ile ilgili çeşitli konulardaki memnuniyetlerini ölçmek adına yöneltilen sorulara (5’li Likert ölçeğine göre) verdikleri cevaplar bu durumu belli ölçüde destekler niteliktedir (Tablo 4).

Tablo 4: Nemrut Kardelen Kayak Merkezi ziyaretçilerinin tesisin sunduğu hizmet ve altyapı olanakları konularındaki görüşleri

Kayak merkeziyle ilgili aşağıda belirtilen konularla ilgili görüşleriniz nelerdir?(\%)

\begin{tabular}{|lll|l|l|l|l|l|}
\hline Çok kötü & 1 & 2 & 3 & 4 & 5 & \multicolumn{7}{l|}{ Çok iyi } \\
\hline Puanlar & 1 & 2 & 3 & 4 & 5 \\
\hline Konaklama olanakları & & 38,0 & 16,0 & 25,2 & 6,7 & 14,1 \\
\hline
\end{tabular}




\begin{tabular}{|l|l|l|l|l|l|}
\hline Yeme-İçme olanakları & 21,1 & 21,7 & 27,1 & 14,5 & 15,7 \\
\hline Ulaşım & 18,0 & 6,6 & 19,8 & 19,2 & 36,5 \\
\hline İletişim & 13,9 & 7,3 & 20,6 & 20,6 & 37,6 \\
\hline Turizm bilgilendirmesi & 50,0 & 18,3 & 18,9 & 4,3 & 8,5 \\
\hline Rekreasyon olanakları & 49,1 & 17,4 & 16,8 & 9,3 & 7,5 \\
\hline Eğlence merkezleri & 57,7 & 15,3 & 15,3 & 5,5 & 6,1 \\
\hline Kayak merkezinin alt yapı olanakları & 24,2 & 18,8 & 25,5 & 17,6 & 13,9 \\
\hline Mekanik tesislerin yeterliliği & 18,9 & 17,7 & 27,4 & 20,7 & 15,2 \\
\hline Pist yeterlilik durumu & 12,2 & 11,6 & 26,8 & 23,8 & 25,6 \\
\hline Kar kalitesi & 3,6 & 6,0 & 16,3 & 27,1 & 47,0 \\
\hline Kayak malzemeleri kiralama olanakları & 17,9 & 8,0 & 31,5 & 19,8 & 22,8 \\
\hline Ürün ve hizmet kalitesi & 19,0 & 10,4 & 29,4 & 25,8 & 15,3 \\
\hline Fiyatların uygunluğu & 39,4 & 12,7 & 23,6 & 13,3 & 10,9 \\
\hline Kış sporları eğitim olanakları & 38,4 & 18,9 & 19,5 & 9,8 & 13,4 \\
\hline Sosyal donatılar (mescit, eğlence merkezi vs.) & 43,6 & 16,0 & 22,1 & 8,0 & 10,4 \\
\hline Acil durum hizmetleri (arama-kurtarma, sağlık vs.) & 47,5 & 19,6 & 17,7 & 4,4 & 10,8 \\
\hline
\end{tabular}

\section{Abalı Kayak Merkezi Kuruluş Yeri Değerlendirmesi}

Abalı Kayak Merkezi Van şehrine yaklaşık 37 km mesafede, Gevaş İlçesi'nin Abalı Mahallesi'nde yer almaktadır. İki etaptan oluşan tesisin birinci etabı 1890-1980 m, ikinci etabı ise 1980-2428 m kotları arasında bulunmaktadır. Mekanik tesislerin birinci etabını $1000 \mathrm{~m}$ uzunluğuna sahip teleski, ikinci etabını ise $1450 \mathrm{~m}$ uzunluğundaki telesiyej oluşturmaktadır. Abalı Kayak Merkezi'nde herhangi bir konaklama tesisi mevcut olmayıp sadece ziyaretçilerin ihtiyaçlarını karşılayabilecekleri kafeterya ve kayak kiralama ofisi bulunmaktadır.
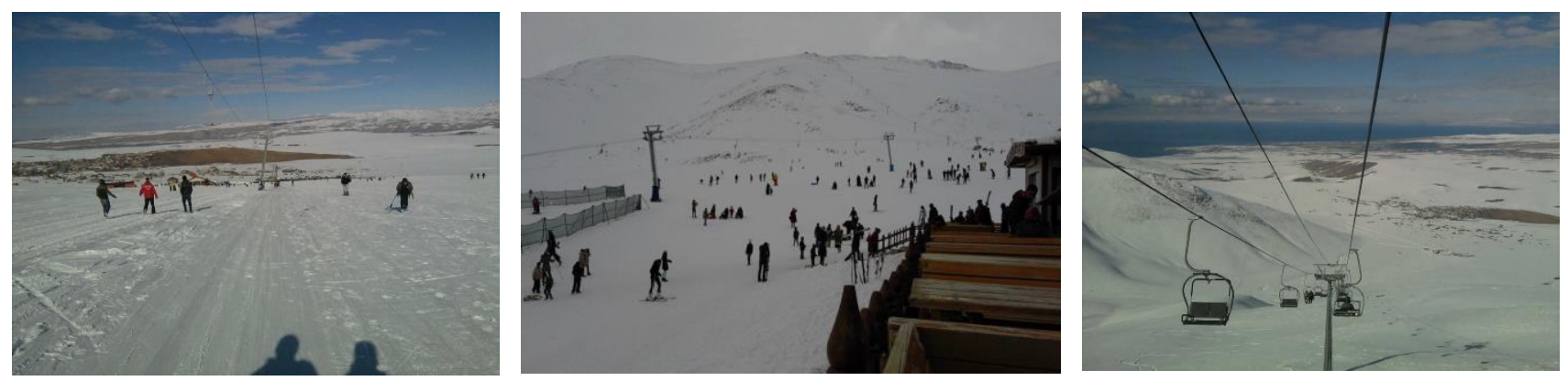

Fotoğraf 2: Abalı Kayak Merkezi genel görünüm

Tesis kapasite itibari ile Van ve yakın çevresinin sayfiye alanı olmanın ötesine gidememiştir. 187 ziyaretçi ile yapılan anket uygulamasında katılımcıların \%90'ının Van'da ikamet ediyor olması tesisin bu özelliğini ortaya koymaktadır. Bu nedenle hitap ettiği kitleye yakınlık ve ulaşılabilirlik 
açısından uygun lokasyondadır. Ulaşım kolay sağlanmakla birlikte sadece özel araçla gidilebilmesi tesisin erişilebilirliğini kısıtlamıştır.

$\mathrm{Bu}$ bağlamda Abalı'da kurulan tesisin yer seçimi konusunda kayak eğitmenleri ve işletme sahipleriyle görüşmeler gerçekleştirilmiştir. Nemrut'ta olduğu gibi burada da öncelikle kayak eğitmenlerinin görüşü ele alınmıştır. Birinci Soru, "Kayak merkezi doğru yerde kurulmuş mu?" A. E1 Bu konuda evet diyebilmeyi çok isterdim. Bu alan ne yazık ki birçok koşul açısından uygun bir yer değil. En büyük problem yeterli kar yă̆ışı alamaması. Bu nedenle zaman zaman tüm sezon boyunca bir gün bile kayak yapamadığımız sezonlar geçiriyoruz. Pistimiz iki etaptan oluşuyor ve tek bir pistimiz var. Arazi olarak bu alan alternatif pistler oluşturmaya uygun değil. Mevcut pistin ikinci etabının zemini de oldukça anzalı. Büyük kaya çıkıntıları var. Bu nedenle kayak yapılması için minimum kar standardının çok üzerinde kar kalınlı̆̆ı lazım. Zaten yetersiz olan kar yă̆ışına bu da eklenince işler daha da zorlaşıyor. Ayrıca ikinci etapta büyük bir rüzgâr sorunumuz var. Rüzgâr pistte kar bırakmıyor. Yağan karı alıp götürüyor. Göl kotuna yakın olması nedeniyle bu alan da ılımanlaştımo bir etki oluyormuş. Bu durumdan dolayı, kar kalitesi olumsuz etkileniyor. Yani anlayacă̆ını kar çabuk eriyor ve gün içerisinde vıcık vıcık oluyor. Buda kayak severlerin istemeyeceği bir durum. A E2. Yer seçimi çok yanlış. Önceki yıllar az da olsa yaklaşık 10-15 gün kayma şansımı oluyordu bu durum gittikçe kötüleşiyor. Oysa çok güzel alanlar var. Bu tesis oralara yapılabilirdi. Buranın en önemli sorunu kar miktarı. Çünkü yağan kar yeterli olmuyor ve pist oluşturma çalışmaları da sürekli aksıyor.

Nemrut'ta olduğu gibi burada da kayak merkezi kurulurken alan uzmanlarının görüşlerinin alınıp alınmadığı sorusu yöneltilmiştir. İkinci soru "Kayak merkezi kuruluşunda sizin fikriniz alındımı?" A E1. Alınmadı. Aksine ikinci etabın yapılmaması konusunda yaptığımız uyarılarda dikkate alınmadı. Yapıldığından bu yana doğru dürüst kullanılmadı. Hakh çıtık. Ama ne fayda kimse işi bilene bir şey sormuyor. Hiç anlamayan birisi yapın buraya diyor yapıyorlar. Görüşünü aldiğımız A E2.'de birinci eğitmen gibi kısmen sitemkâr bir yaklaşım sergilemiştir. Özellikle yerel yöneticilerin (ilin en büyük mülkü amirleri) kararları kendi başlarnna ya da konu uzmanı olmayanlarla birlikte aldıklarnı ve büyük ölçüde de diğer kurum amirlerinin farklı görüşleri olsa dahi bu durumun sahaya yansımadığın ifade etmiştir.

Üçüncü soru "Kayak merkezinin kar kalitesi ve karn yerde kalma süresi ile ilgili ne düşünüyorsunuz?" A. E1 ben dünyanın çok yerinde uluslararası organizasyonlara katılan, dünyanın en gözde kayak merkezlerinde kayma firsat bulan bir kişiyim. O yüzden kıyaslama yapabilecek deneyime sahibim. Buradaki kar ve pist kalitesi ne yazık ki vasat durumda. Bence bu tesis en kısa zamanda daha uygun bir alana taşınmalı. A. E2 Daha öncede söyledim buranın sorunu kar yokluğu. Ya az yağıyor ya da eriyen karlar kayak yapmak için pist oluşumuna izin vermiyor. Tabi bu söylediklerim her geçen gün daha kötüye gidiyor. Eskiden özellikle Ocak ve Şubat aylarında nispeten kar olurdu ve kısmen de olsa kayak yapılırdı. Ancak şimdi Ocak'ta da Şubat'ta da kar yağmıyor ve yağan karda bu alanda uzun süre kalamıyor.

Dördüncü soru "Kayak Sezonunun uzunluğunda süreç içerisinde bir değişiklik oldu mu?" A. E1 Değişiklik derken sezon boyunca hiç açılamadiğg yıllar oldu. Sezonun bir standardı yok burada maalesef. Diyemiyoruz şu tarihle şu tarih arasında kayak yapmak mümkün diye. A. E2 Oldu tabi ki, tesisin açıldiğg ilk zamanlarda az da olsa kayak yapılıyordu. Düzenli değildi ama yine de hemen hemen her yıl kayak yapmak kısmen mümkündü. Ama şimdi değil. Fakat başından beri kaliteli kayak yapmak hiç mümkün olmadı. Karın çok yağdığı yıllarda dahi buranın sezonu kısa olurdu.

Beşinci soru "Sizce bu merkez ulusal ve uluslararası organizasyonlara ev sahipliği yapabilir mi?" A. E1 Biz burayı daha çok genç sporcuları eğitmek için kullanıyoruz. Çoğunlukla eğitim faaliyetlerimiz bile aksıyor. Bu nedenle büyük ölçekli bir organizasyon planlayabilecek bir altyapıya sahip değiliz. Hava şartlarının uygun olduğu dönemlerde küçük çapl yarışlar düzenlendi ama sürdürülebilirliğ olmadı. Olması da bence mümkün değil zaten. A. E2 Hocam bence bu soruyu hiç sormamıs olun. Burası bırakın ulusal, uluslararası organizasyonları yerel organizasyonlara bile ev sahipliği yapamaz. 
Altıncı soru "Kayak merkezi sizce bölge insanının ihtiyacını karşılıyor mu?" A. E1 Bölge insanının ihtiyacını kısmen karşılıyor. Çünkü buraya gelen insanları \%90'ı zaten Van'lı. Çoğunluğu da kayak yapmak için değil piknik yapıp çocuklarnı eğlendirmek için geliyor. Bu nedenle beklentileri çok yüksek olmayan bu insanlarn taleplerini de karşıladığın düşünüyorum. Tabi kayak tutkunlan için ayn şeyi söylemem mümkün değil. A. E2 Açık olduğunda insanlar kullanıyor. Ama burada şöyle bir sorun var. Burada karın varlığı ya da kayak yapılabilir olduğu bilgisi düzenli paylaşılmıyor. Dolayısıyla insanların çoğunun kayak yapılabildiğinden haberi bile olmuyor. Ancak çok ilgili olanlar kayabiliyor. Bunun nedeni de çoğunlukla pistin düzenli çalışmaması ve çoğu zaman kapalı olması.

Abalıda eğitmenler kadar sahadaki gelişmeleri yakından takip eden bir diğer bileşen ise kafeterya işletmecisidir. İşletme yöneticisi altı sorudan oluşan mülakat sorularına şu cevapları vermiştir. Birinci soru, "İşletmeniz kaç ay açık kalıyor?" Yıldan yıla deşiyor maalesef bazen kayak yapmaya yetecek kadar yă̆ış alamadı̆̆ımı zamanlar oluyor. Tüm sezon boyunca bir gün bile hizmet veremeyebiliyoruz. O yüzden sezon uzunluğuyla ilgili bir standardımız yok. İkinci soru, "Ziyaretçileriniz ă̆ırlıklı olarak nereden geliyor?" Ziyaretçilerimizin tamamına yakın Van'dan ve ilçelerinden geliyor. Çok az sayıda yakın illerden de misafirlerimiz olabiliyor. Üçüncü soru, "Burayı ziyaret edenler kayak deneyiminden memnunlar mı?" Memnuniyet insanların ne bekledikleri ile alakalı bir durum. Biz burada insanlarn boş zamanlarn değerlendirebilecekleri bir alternatif sunuyoruz. Hitap ettiğimiz kesim çoğunlukla kayak konusunda çok beklentisi olan bir kitle değil. Buraya geldiklerinde farklı bir şeyler yapıyor olmak da onlar memnun etmeye yeterli oluyor diye düşünüyorum. Dördüncü soru, "Sizce bu yer kayak merkezi için uygun mu?" Bir kayak merkezi için uygun koşullar sağlayan bir yer değil ne yazık ki. İşletme performansımız bunu kanıtlıyor. Her yıl aynı standartta çalışamıyoruz. Seneye açılış yapabilecek miyiz bilmiyoruz. Bunun temel sebebi de buranın kayak sporunun gerektirdiŏi doğal şartları tam anlamıla sağlayamamasıyla alakah olsa gerek. Beşinci soru, "Altyapı ve üst yapı imkanlan iyileşirse ziyaretçi sayısı artar mı?" Açıkçası kış sporları için uygun olmayan bir yerde en modern mekanik altyapıları da kursanız, en yüksek standartlara sahip sosyal tesisler de inşa etseniz amacına uygun hizmet üretilemeyeceğini düşünüyorum. Öyle olunca da ziyaretçi sayısının da çok artamayacağın düşünüyorum. Çünkü doğal koşullar açısından kapasitemiz ortada. Altıncı soru, "Kayak merkezine gelen kişiler bu işetmeleri (yiyecek-içecek amaçlı) ne sıklıkla(ölçüde)kullanıyor?" Hizmete açık olduğumuz zamanlarda ziyaretçilerimiz işyerimizi yoğun şekilde kullanıyor. Çaydır, yiyecek içecektir bizden alıyorlar. Ama gelenlerin önemli bir kısmı da ailesiyle piknik yapmaya geliyor. Kendi getirdiğini yiyor içiyor. Burada hiç para harcamadan dönüp gidiyor. Kayak da yapmiyor zaten o yüzden telesiyeji de kullanmyor. Bu nedenle bize hiçbir katkısı olmuyor bu tarz insanların.

Bu bağlamda sporcu eğitim alanı ve yerel sayfiye merkezi özelliği gösteren ve Van Gölü manzarası eşliğinde kayak imkânı sunan söz konusu kayak merkezinin kuruluş yeri tercihinin doğru olmadığı anlaşılmaktadır. Sahanın en önemli sorunu yeterli kar yağışını alamamasıdır. Van Gölü yüzey kotuna yakın bir irtifada bulunması nedeniyle oluşan ılımanlaştırıcı etki tesise düşen kar şeklindeki yağış miktarını nispeten azaltmaktadır. Sonuç itibariyle dönem dönem kar azlığı nedeniyle tesis açılış dahi yapmadan sezonu kapatmaktadır. Öyle ki 2017-18 ve 2018-19 sezonlarında bu nedenle hiç faaliyet gösterememiştir. Yaşanan bu durumlar yerel klimatik dinamikler gereği tesisin kar yağışı açısından uygun yükselti kuşağında kurulmadığını göstermektedir. Kar miktarı yeterli olsa dahi sıcaklık ve yüksek nem oranı kar kalitesini düşürmektedir.

Öte yandan sahanın ikinci etabında rüzgâr nedeniyle pistin kar tutmadığı gözlemlenmiştir. Normal şartlarda düzgün zeminde $30 \mathrm{~cm}$ kalınlığındaki kar ezildiğinde kayak yapmaya olanak vermektedir. Ancak Abalı Kayak Merkezi'nin ikinci etabında zeminin taşlı ve arızalı yapısından dolayı kayak yapılabilmesi için çok daha kalın bir kar örtüsüne ihtiyaç duyulmaktadır. Ancak rüzgâr süpürmesi çoğu zaman istenilen kalınlıkta bir kar örtüsünün oluşmasına engel olmaktadır. 
Kayak yapabilmek için ön koşul olan yeterli miktarda karla örtülü bir zeminin olmayışı ankete katılan ziyaretçilerin memnuniyetini de etkilediği görülmüştür. Pist zeminini kaplayan kar örtüsünün en amatör kişilerin dahi beklentisini karşılayamayacak düzeyde olması nedeniyle kar kalitesi düşük puanlanmıştır. Aynı zamanda bu nedenden ötürü bir çekicilik olarak da görülmemiştir.

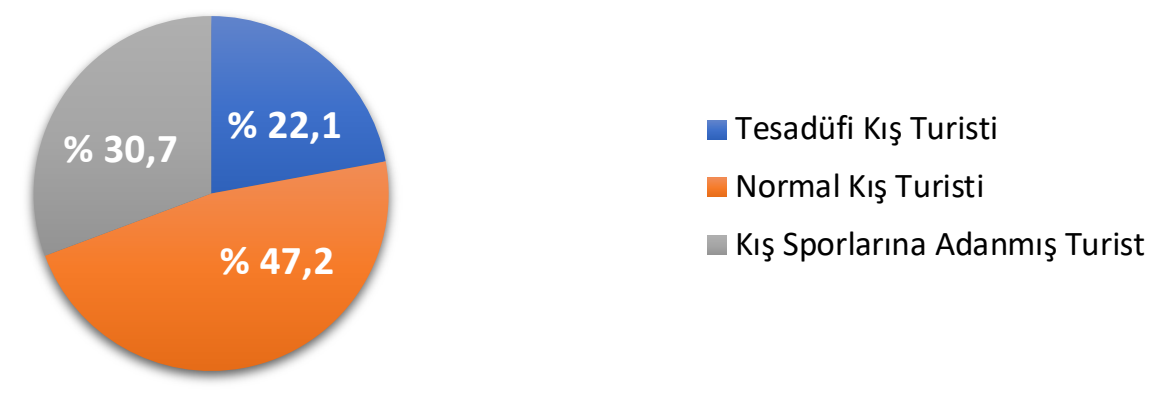

Grafik 2: Abalı Kayak Merkezi'nde ziyaretçilerin kendilerini nasıl tanımladıkları

Tablo 5: Abalı Kayak Merkezi'nin katılımcılara göre en önemli çekiciliği

\begin{tabular}{|l|l|l|}
\hline Sizce bu merkezin en önemli çekiciliği nedir? & Kişi sayısı & $\%$ \\
\hline & 126 & 67,7 \\
\hline Yaşadığım yere yakınlık & 2 & 1,1 \\
\hline Tesis ve pist kalitesi & 7 & 3,8 \\
\hline Kar kalitesi & 26 & 14,0 \\
\hline Manzara ve doğal güzellikler & 3 & 1,6 \\
\hline Hizmet kalitesi & 22 & 11,8 \\
\hline Diğer & 3 & \\
\hline
\end{tabular}

Kayak merkezinde iki etaplı tek bir pist bulunmaktadır. Birinci etabı düşük eğimli kolay pist, ikinci etabı ise orta dereceli pist özelliğindedir. Fakat alanda alternatif pistler oluşturacak uygun eğimli yamaçlarda kısıtlıdır. Bu nedenle kayak alanının genişletilmesi de mümkün değildir. Sonuç olarak tüm bu olumsuzluklar yüksek maliyetlerle gerçekleşen bu yatırımın yanlış lokasyon tercihi nedeniyle istenilen düzeyde hizmet üretemediğini göstermektedir.

Tablo 6: Abalı Kayak Merkezi'nde ziyaretçilerinin tesisin sunduğu hizmet ve altyapı olanakları ile ilgili görüşleri

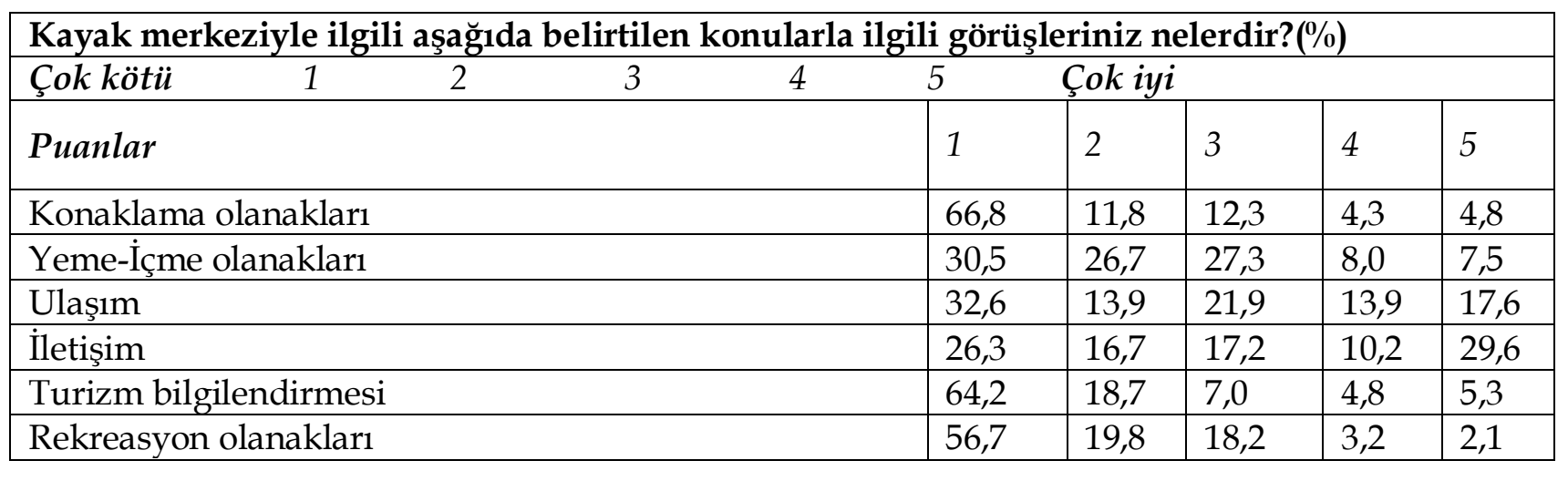




\begin{tabular}{|l|l|l|l|l|l|}
\hline Eğlence merkezleri & 58,8 & 22,5 & 8,6 & 3,7 & 6,4 \\
\hline Kayak merkezinin alt yapı olanakları & 28,0 & 22,6 & 29,0 & 11,3 & 9,1 \\
\hline Mekanik tesislerin yeterliliği & 21,9 & 18,2 & 36,4 & 15,0 & 8,6 \\
\hline Pist yeterlilik durumu & 26,2 & 16,6 & 28,9 & 15,5 & 12,8 \\
\hline Kar kalitesi & 24,1 & 19,8 & 22,5 & 24,1 & 9,6 \\
\hline Kayak malzemeleri kiralama olanakları & 30,6 & 16,1 & 16,7 & 17,7 & 18,8 \\
\hline Ürün ve hizmet kalitesi & 13,9 & 26,7 & 31,6 & 18,2 & 9,6 \\
\hline Fiyatların uygunluğu & 39,0 & 18,2 & 32,1 & 6,4 & 4,3 \\
\hline Kiş sporları eğitim olanakları & 27,8 & 20,9 & 29,9 & 13,4 & 8,0 \\
\hline Sosyal donatılar(mescit, eğlence merkezi vs.) & 41,2 & 23,5 & 24,1 & 5,3 & 5,9 \\
\hline Acil durum hizmetleri(arama-kurtarma, sağlık vs.) & 24,1 & 10,7 & 20,3 & 7,5 & 37,4 \\
\hline
\end{tabular}

Hizmet üretemeyen bir işletmenin müşterilerini memnun edebilmesi mümkün değildir. Abalı Kayak Merkezi tamamen yanlış yer seçimine bağlı olarak düzgün hizmet veremeyen bir tesistir. Her açıdan kısıtlı bir altyapıya sahip olması ziyaretçilerin memnuniyet düzeylerini de olumsuz yönde etkilemiştir. Tesisin sunmuş olduğu hizmetler ve altyapı olanaklarını puanladikları tablo bu durumu ortaya koymaktadır.

\section{SONUÇ VE ÖNERİLER}

Yer seçimi konusu yalnızca kayak merkezleri için değil insana ilişkin her türlü işletme için önemli bir konudur. Dolayısıyla kayak merkezlerinin yer seçiminin doğru yapılması, verimlilik başta olmak üzere çevrenin koruması ve sosyo-kültürel gelişmeler açısından da oldukça önemlidir. Zira yüksek maliyetlerle yapılan söz konusu tesislerin doğru alanlarda inşa edilmesi ekonomik kazanımlar yanında yeni bir kültürün gelişimine ve yöre insanı için sosyalleşme alanının yaratılmasına katkı sunmaktadır. Aksi durumda çalışmamıza konu olan örneklerde olduğu gibi önemli miktarda ulusal sermaye ve insan emeği israfına neden olmaktadır. Uygun olmayan yer seçimleri çevreyi kirletip bozabileceği ve geri dönüşü olmayan zararlar verebileceği için de kayak merkezlerinin kuruluş yeri tercihi çok önemlidir (Tsuyuzaki, 1994). Kayak alanı konumlarının bilimsel ölçülere göre değerlendirilmesi, ortaya çıkabilecek olumsuz sonuçları azaltmaya yardımcı olmak için bir ön koşuldur (Akt. Deng \& vd., 2019). Bu nedenle, kusursuz bir lokasyon tercihi için alanında uzman kişilerin görüşüne başvurulmalı, teknolojik alt yapı kullanılmalı ve kapsayıcı bir planlama süreci yürütülmelidir. Dahası tüm değişkenler göz önünde bulundurulmalı ve belirlenecek alanlarda her türlü riske karşı simülasyonlar gerçekleştirilmelidir. Sadece bütün koşulları sağlayan alanlarda yatırım aşamasına geçilmelidir.

Bu bağlamda, Van ve Bitlis, fiziki şartların yarattı̆̆ koşullar nedeniyle kış sporlarına uygun alanlara sahip illerden ikisidir. Söz konusu iller, hem kaliteli ve yüksek standartlı pistlerin oluşturulması için uygun eğim değerlerine hem de uygun bakı koşullarına sahip yamaçlara ve yeterli kar yağışının gerçekleşmesi için elverişli yükselti kuşağında sahiptirler (Aydın, 2016). Ancak bu çalışma göstermiştir ki böylesine uygun alanların varlığına rağmen bu illerde yer alan tesislerin tamamı yanlış lokasyonlarda kurulmuştur. Yapılan saha araştırmalarında her iki kayak merkezinin yer seçimi de konu uzmanlarından oluşan bir ekip tarafından değil yerel idarecilerin kişisel tasarrufları doğrultusunda belirlendiği anlaşılmıştır. Göl manzarasını izleyerek kayak yapmanın bir ayrıcalık olacağı ve kış sporu tutkunlarını kendine çekeceği düşüncesiyle asıl olması gereken doğal ortam şartlarını sağlamayan bir lokasyonun tercih edilmesi hata olmuştur.

Yanlış yer seçimi nedeniyle her iki merkezde kesintisiz hizmet üretememektedir. Sezonlarının sürekli olarak kesintiye uğraması ve kaliteli kış sporu yapmaya uygun olmayan koşulları nedeniyle ulusal ve uluslararası organizasyonlara ev sahipliği yapabilecek durumda değildirler. Tesadüfi olarak tüm şartların iyi gittiği dönemlerde küçük çaplı organizasyonlar yapılmış olsa da hiçbirinin sürdürülebilirliği olmamıştır. Tüm dünyada kış sporları turizminin 
küresel iklim değişikliği tehdidiyle karşı karşıya olduğu da göz önünde bulundurulduğunda zaten koşulları yetersiz olan bu merkezler tamamen faaliyet gösteremez hale geleceklerdir. Son yıllarda yağışın şeklinde yaşanan değişim (kar şeklinde düşen yağışlar yağmur şeklinde düşmeye başlamıştır) ve Ekim ayında düşmesi beklenen karın Aralık ayı sonlarına yağması daha vahim bir görüntünün oluşmaya başladığını göstermektedir.

Turistlerin hizmet kalitesi algıları memnuniyet duygularını etkilemekte, buda sadakatlerinde ve gelecekteki satın alma kararlarında belirleyici olmaktadır (Bédiová \& Ryglová, 2015). Bir turizm yatırımının müşterisini memnun edebilecek kalitede hizmet sunabilmesi istikrarlı ve kaliteli hizmet üretmesine bağlıdır. Bu ise ancak yeterli kar ve kaliteli kar koşullarının sağlanmasıyla mümkündür. Bu koşulu sağlayamaması nedeniyle düzensiz hizmet üretmesi kış sporu tutkunlarının bu alanları tatil planlarına dahil etmeleri de zorlaşmaktadır. Çünkü kış turistlerinin destinasyon tercihini belirleyen en önemli motivasyonları yeterli miktarda kar güvenliği(yani karın her zaman olacağını bilmeleri) ve toz kar varlığıdır (Klenosky, Gengler, \& Mulvey, 1993). Turizm ani kararlarla gerçekleşen bir faaliyet değildir. İnsanlar tatil planlarını bazen bir yıl bazen de daha da önce planlayabilmektedirler. Bu nedenle sezonu açıp açamayacağı belli olmayan bir kayak merkezini kimse tatil planına dahil etmeyecektir. Abalı ve Nemrut'taki yanlış yer seçimine bağlı olarak sezonlarının istikrar göstermeyişi bu durumla karşı karşıya kalmaları sonucunu doğurmaktadır. Sonuç olarak da hizmet verebildiği sürece yerel insanların sürekli kullanabildiği, ulusal veya uluslararası turistlerin ise tesadüfi olarak faydalanabildikleri merkezlere dönüşmeleri kaçınılmaz olmuştur.

Nemrut Kardelen Kayak Merkezinde alınacak bazı önlemler kayak sezonunu kısmen uzatabilecektir. Özellikle en büyük problemlerden birini teşkil eden rüzgâr süpürmesini önlemek adına piste paralel olarak rüzgâr panellerinin yapılması pistlerde karın daha uzun muhafaza edilmesini sağlayarak bu sorunu önemli ölçüde çözecektir. Ancak bakı nedeniyle aşırı güneşlenmenin önüne geçilemeyeceği için sorunları tamamen ortadan kaldırmak mümkün olmayacaktır. Maksimum verimle çalışabilecek bir tesis ancak bu alandaki tüm teknik altyapının bütün koşullar açısından elverişli başka bir yere taşınmasıyla mümkün olabilecektir.

Abalı Kayak Merkezinde ise sorunların etkisini azaltabilecek geçici önlemler dahi hiçbir çözüm üretmeyecektir. Tesis kesinlikle başka bir alana taşınmalıdır. Çalışma kapsamında bu tesisin taşınabileceği uygun bir lokasyon belirlenmeye çalışılmıştır.

Bu bağlamda, Van ili Gevaş İlçesi Dokuzağaç Mahallesi'nin güneyindeki dağlık alan kış sporları için oldukça elverişli şartlara sahip olduğu anlaşılmaktadır. Gevaş Gençlik ve Spor Dairesi kayak uzmanının da katılımıla gerçekleştirdiğimiz arazi çalışmaları sonucunda bu alanın kış sporlarına uygun şartlar sağladığı tespit edilmiştir. Bu alan öncelikle eğim ve bakı şartları açısından elverişli koşullara sahiptir. Yaklaşık $3100 \mathrm{~m}$ yüksekliğe ulaşan zirveden itibaren uygun yamaç koşullarının varlığı farklı uzunluk (2 ila $4 \mathrm{~km}$ ) ve zorluk derecelerine sahip (usta-acemi) pistlerin düzenlenebilmesine olanak sağlamaktadır. Ek olarak akarsuların oluşturduğu tekne biçimli vadiler snowboard etkinliği için doğal pistler olarak kullanım imkânı vermektedir. 


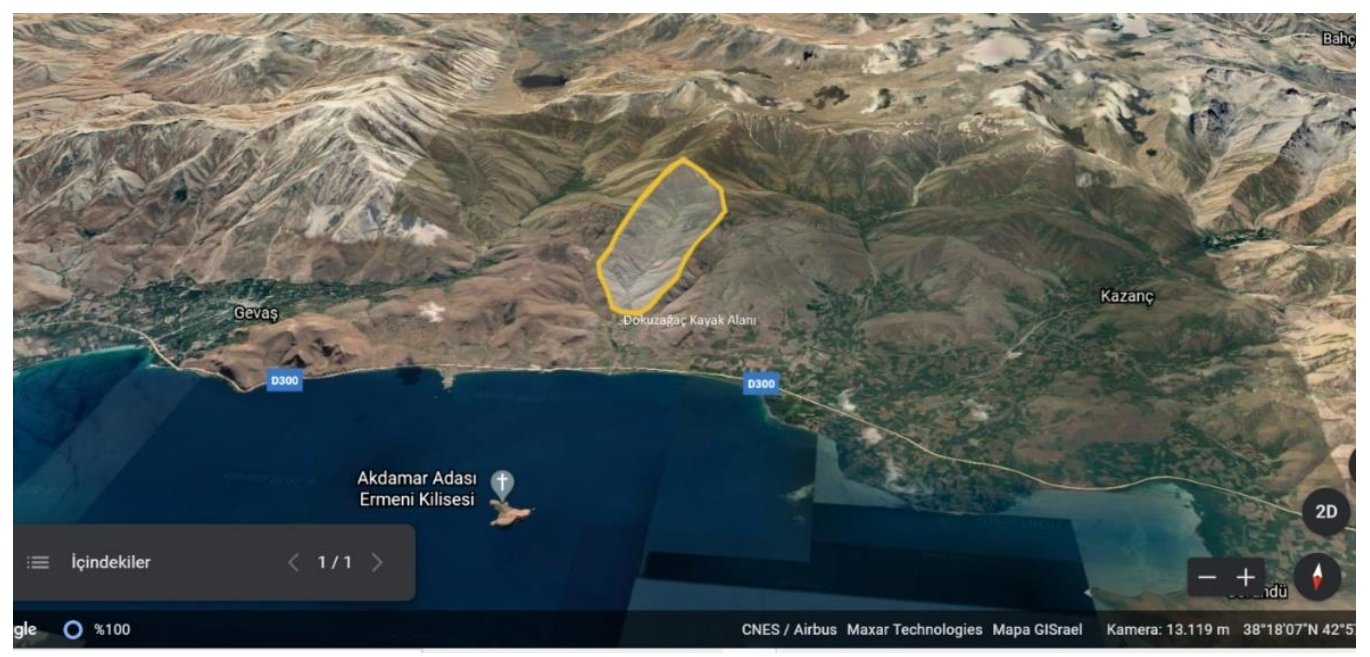

Şekil 1: Dokuzağaç Kayak Alanı ve çevresinin uydu görüntüsü (GoogleEarth, 2020)

Birkaç noktada kendini gösteren kaynak suyu çıkışları da ilaveten bir avantaj oluşturmaktadır. Bu kaynaklar hem tesisin kullanımı açısından önem arz ederken hem de özellikle tüm dünya kayak merkezlerinde ihtiyaç haline gelen yapay kar makineleri için de gereklidir. Ek olarak sahanın eğim ve bakı durumları da aşağıdaki tabloda ayrıntıları görüleceği üzere oldukça elverişli durumdadır (Aydın, 2016).
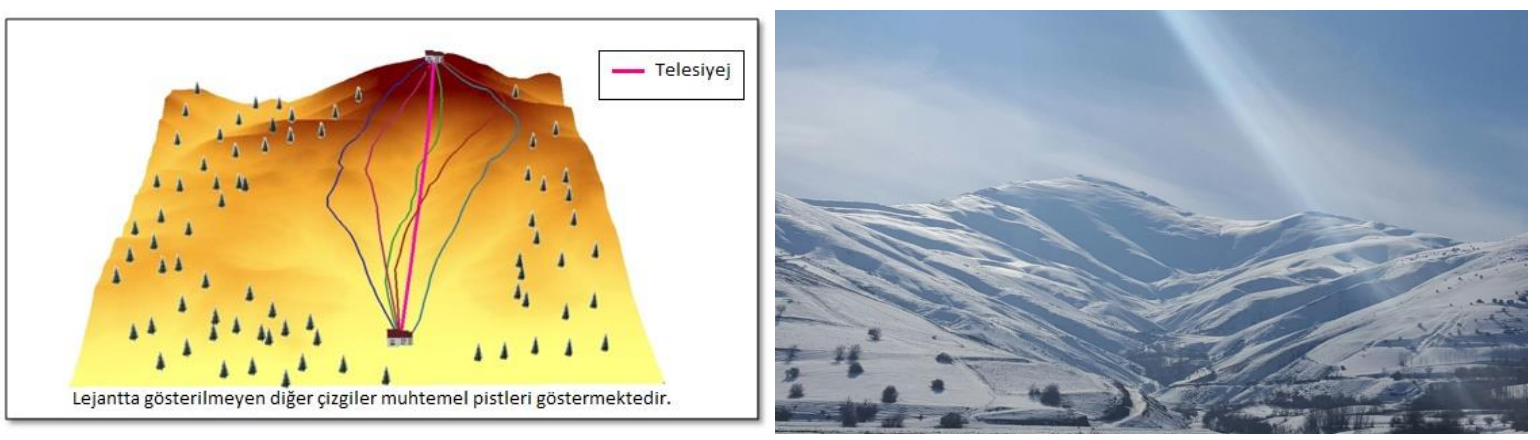

Şekil 2: Dokuzağaç Kayak Alanı muhtemel pist şeması ve alandan genel görünüm

Tablo 7: Dokuzağaç potansiyel kayak alanı eğim ve bakı durumu

\begin{tabular}{|l|l|l|l|}
\hline Eğim & \multicolumn{2}{l|}{ Bakı } \\
\hline Ĕ̈im Dĕ̆eri & Oranı(\%) & Bakı Yönü & Oranı(\%) \\
\hline$\% 50+$ & 1,3 & Kuzey & 11,83 \\
\hline$\% 30-50$ & 27,24 & Kuzeydoğu & 14,52 \\
\hline$\% 15-30$ & 43,27 & Kuzeybatı & 18,84 \\
\hline$\% 10-15$ & 13,73 & & \\
\hline
\end{tabular}

Bu alanda kurulacak kayak merkezi önemli çekiciliklere sahip olacaktır. Bu çekiciliklerin en önemlisi şüphesiz Van Gölü ve Akdamar Adası manzarası eşliğinde verimli bir kayak yapma ayrıcalığı sunacak olmasıdır. Buna ek olarak hemen yanı başındaki Artos Dağı da ayrı bir görsel güzellik sunmaktadır. Ulaşılabilirlik açısından da oldukça elverişli bir konumda yer almaktadır. Van-Bitlis karayoluna sadece $1 \mathrm{~km}$ gibi kısa bir mesafede kurulabilecek tesisler sadece kış turistlerine değil farklı amaçlarla gelen ziyaretçilere de hizmet sunabilecektir. Özellikle Akdamar Adası'na yakınlığı nedeniyle burayı ziyarete gelenlerin de kullanabileceği bir merkez olacaktır. Böylece tesis yaz ve kış aylarında hem yerel halka hem de bölgeyi ziyaret eden kayak severlere hizmet verebilecektir. 


\section{Kaynakça}

Akın, A., \& Erdoğan, M. A. (2017). Uzaktan Algılama ve Coğrafi Bilgi Sistemleri Yardımıyla Aladağlar'da Kış Sporları İçin Uygun Alanların Belirlenmesi. Artvin Çoruh Üniversitesi Orman Fakültesi Dergisi, 201-210.

Alaeddinoğlu, F., Can, A. S., \& Yılmaz, E. (2011). Van Gölü Havzası Batı Kesiminde Ekoturizm: Potansiyel Kaynaklarn Derecelendirilmesi ve Turist Profilinin Belirlenmesi. Van: Yüzüncü Yıl Üniversitesi.

Aydın, B. (2016). Van ve Bitlis İllerinde Kış Turizm Potansiyelinin Belirlenmesi ve Planlamaya Yönelik Öneriler. Van: Van Yüzüncü Yıl Üniversitesi Sosyal Bilimler Enstitüsü Yayınlanmamış Yüksek Lisans Tezi.

Bédiová, M., \& Ryglová, K. (2015). Satısfaction And Loyalty Factors Of Sk1 Resorts - The Case Study Of Slovakia And Austria. Proceedings of the 2015 International Conference "Economic Science For Rural Development", (s. 37-45). Jelgava.

Bocchiaro, J. (Erişim 11.12.2020). Slopes, Skis, and Standards: Having Fun Skiing Safely, Responsibly, and Sustainably. 2013 ANSI/NIST/SES World Standards Day Paper Competition Submission: https://cdn.ymaws.com/www.ses-standards.org/resource/resmgr/imported/Slopes\%20 Skis\%20and\%20Standards-Bocchiaro.pdf adresinden alınd1

Demiroğlu, O. C. (2013). İklim Değişikliğinin Kış Turizmine Etkisi. İstanbul: İstanbul Üniversitesi Sosyal Bilimler Enstitüsü Yayınlanmamış Doktora Tezi.

Demiroğlu, O. C. (2014). Kış Turizmi. Ankara: Detay Yayıncılık.

Deng, J., Che, T., Xiao, C., Wang, S., Dai, L., Meerzhan, A. (2019). Suitability analysis of ski areas in China: an integrated study based on natural and socioeconomic conditions. The Cryosphere, Volüme: 13 - Issue: 8, 2149-2167.

Doğaner, S. (2012). Türkiye'nin Dağlık Alanlarında Kış Turizmini Etkileyen Coğrafi Etmenler. Coğrafya Dergisi (0)5, https://dergipark.org.tr/tr/pub/iucografya/issue/25054/264509 , 19-44.

Elsasser, H., \& Burki, R. (2002). Climate change as a threat to tourism in the Alps. Climate Research, Volume: 20, 253-257.

Erol, O. (2004). Genel Klimatoloji (6.baskı). İstanbul: Çantay Kitapevi.

Fengru, C., \& Guitang, L. (2019). Analytical Framework of Microcosmic GPN Studies. C. F. Guitang içinde, Global Value Chains and Production Networks (s. 41-68). https://doi.org/10.1016/B978-0-12-814847-1.00003-8: https://www.sciencedirect. com/science/article/pii/B9780128148471000038.

Fukushima, T., Kureha M., Ozaki, N., Fujimori, Y., Harasawa, H. (2002). Infuluences of Air Temperature Change on Leissure Industries: Case Study on Ski Activities. Mitigation and Adaptation Strategies for Global Change, Volume: 7, 173-189.

Giambrone, E. (2011). Montana Ski Area Suitability Analysis. https:/ / sites.tufts.edu/gis/files/2013/11/Giambrone_Eric.pdf (12.11.2020 erişildi).

Gilaberte-Búrdalo, M., Lopez-Moreno, I.J., Moren-tejeda, E., Jerez, S., Alonso-Gonzales, E., LopezMartin, F., Pino-Otin, M, R. (2017). Assessment of ski condition reliability in the Spanish and AndorranPyrenees for the second half of the 20th century. Applied Geography, Volume: 79, 127142.

Gorter, C., \& Nijkamp, P. (2001). Location Theory. N. J. Smelser, \& P. B. Baltes içinde, International Encyclopedia of the Social $\mathcal{E}$ Behavioral Sciences (s. 9013-9019). https://www.sciencedirect.com/topics/economics-econometrics-and-finance/locationtheory. 
Gövsa, Ö. (Erişim 11.13.2020). IZZMIR DAĞ PROJESİ: İzmir Bozdă̆ Kayak Merkezi Eleştirileri ve Geleceği. http://www.dagprojeleri.com/tr:http://www.dagprojeleri.com/tr_izmirdagpro jeleri.aspx ?id=1 adresinden alınd 1

Günal, N. (2013). Türkiye'de Kar Yağışı, Karın Yerde Kalma Süresi ve Daimi Kar Sınırı. Acta Turcica(Çevrimiçi Tematik Türkoloji Dergisi), Sayı:1,1-13.

Gürbüz, S., \& Şahin, F. (2017). Sosyal Bilimlerde Araştırma Yöntemleri. Seçkin Yayınları.

Hodeck, A., \& Hovemann, G. (2015). Destınation Choice In German Winter Sport Tourısm: Empirical Findings. Polish Journal of Sport and Tourism, Volume 22: Issue 2, 114-117, DOI: 10.1515/pjst-2015-0019.

İkizceli, İ., \& Akdeniz, Y. S. (2017). Akut Dağ Hastalığı ve Serebral Ödem. Turkiye Klinikleri Emergency Medicine-Special Topics, 3(3) , 252-259.

Klenosky, D. B., Gengler, C. E., \& Mulvey, M. S. (1993). Understanding the Factors Influencing Ski Destination Choice: A Means-End Analytical Approach. Journal of Leisure Research; Volume: $25 ; 4,362-379$.

Konu, H., Laukkanen, T., \& Komppula, R. (2011). Using Ski Destination Choice Criteria to Segment Finnish Ski Resort Customers. Tourism Management, Volume: 32, Issue: 5, 1096-1105.

Koyuncu, R. (Erişim 11.12.2020). YÜKSEK İRTIFA ve YÜKSEK İRTIFA HASTALIKLARI . https://www.

researchgate.net/publication/332408108_YUKSEK_IRTIFA_ve_YUKSEK_IRTIFA_HASTALI KLARI_Rozerin_Koyuncu adresinden alındı

Mızrak, O. (2011). Kayak Alanlarının Yönetimi ve Güvenliği: Palandöken Kayak Merkezi Uygulaması. Ankara: Gazi Üniversitesi Sağlık Bilimleri Enstitüsü Beden Eğitimi ve Spor Anabilim Dalı Yayınlanmamış Doktora Tezi.

Morey, E. R. (1984). The Choice of Ski Areas: Estimation of a Generalized CES Preference Ordering with. The Review of Economics and Statistics, Volum: 66, No. 4, 584-590.

Morey, E. R. (1985). Characteristics, Consumer Surplus, and New Activities: A Proposed Ski Area. Journal of Public Economics, Volume: 26, Issue: 2, 221-236.

Pearce, P. L. (2005). Tourist Behaviour: Themes and Conceptual Schemes. Clevedon: Channel View Publications.

Riddington, G., Sinclair, C., \& Milne, N. ( 2000). Modelling Choice and Switching Behaviour Between Scottish Ski Centres. Applied Economics, Volume: 32, , 1011-1018.

Rixen, C., Teich, M., Lardelli, C. (2011). Winter Tourism and Climate Change in the Alps: An Assessment of Resource Consumption, Snow Reliability, and Future Snowmaking Potential. Mountain Research and Development, 31(3), 229-236.

Scott, D., McBoyle, G., \& Minogue, A. (2007). Climate change and Quebec's ski industry. Global Environmental Change, Volume: 17, Issue: 2, 181-190.

Tsuyuzaki, S. (1994). Environmental Deterioration Resulting from Ski-resort Construction in Japan. Environmental Conservation, Volume:21, https://doi.org/10.1017/S0376892900024541, 121-125.

Siberman, J. A., \& Ress, P. W. (2010). Reinventing Mountain Settlements: A GIS Model for Identifying Possible Ski Towns in the U.S. Rocky Mountains. Applied Geography, Volume: 30, $36-49$.

Ülker, İ. (1992). Dă̆ Turizmi: Planlama Yöntemler, Yüksek Dă̆larımız, Kayak Merkezleri. Ankara: T.C.Turizm Bakanlığı.

Vanat, L. (2019). 2019 International Report on Snow \& Mountain Tourism . https://vanat.ch/RMworld-report-2019.pdf. 
Won, D., Bang, H., \& Shonk, D. J. ( 2008 ). Relative Importance of Factors Involved in Choosing a Regional Ski Destination: Influence of Consumption Situation and Recreation Specialization. Journal of Sport \& Tourism, Volume 13, Issue 4, 249-271.

Yavan, N. (Erişim 10.11.2020). Yerseçim (Lokasyon) Teorisine Giriş. https://acikders.ankara.edu.tr/pluginfile.php/90985/mod_resource/content/0/Hafta11Lokasyon \%20\%28Yerse\%C5\%9Fim\%29\%20Teorisine\%20Giri\%C5\%9F.pdf adresinden alınd1

Zeydan, Ö., \& Sevim, B. (2008). İklim Değişikliğinin Kış Turizmine Etkisi. TMMOB İklim Değişimi Sempozyumu: Küresel İklim Değişimi Ve Türkiye (s. 156-171). Ankara: TMMOB.

Google Earth (Erişim 19.11.2020). https://earth.google.com/web/@38.30608579, 43.07217352,832.88361535a,20960.0823556d,35y,171.43755871h,60.11819946t,0r adresinden alind 1

www.travel-information.org. (Erişim 13.11.2020). travel-information.org. https://travel-information .org/ski-slope- ratings/ adresinden alındı

https://en.wikipedia.org. (Erişim 13.11.2020). Piste. https://en.wikipedia.org/ wiki/Piste\#: :text=The\%20steepness \%20of\%20ski\%20trails,) $\% 20$ are $\% 2040 \% 25 \% 20$ and $\% 20 \mathrm{u}$ p. adresinden alınd 1 